Cuadernos de Historia Contemporánea

ISSN: 0214-400X

http://dx.doi.org/10.5209/chco.71904

\title{
Los «grupos de afinidad», actores del proceso cultural y societario ácrata (España, 1930-1939)
}

\author{
Alejandro Lora Medina ${ }^{1}$
}

Recibido: 17 de abril de 2018 / Aceptado: 11 diciembre 2019

Resumen. El objetivo del presente artículo es analizar las características y la importancia de los grupos de afinidad anarquista en los años treinta dentro del movimiento libertario español. La heterodoxia ácrata encuentra en estos grupos de ámbito local y autonomía de acción la vía para crear una militancia combativa y revolucionaria. El fomento de la cultura se convierte en el pilar central de la actuación de estos colectivos. Analizaremos el origen, función, sentido e idiosincrasia de la estructura organizativa básica del movimiento libertario español, y cómo los cambios políticos iniciados tras el inicio de la Guerra Civil permitiría que la FAI convirtiera a los grupos de afinidad en un instrumento para conseguir mayor influencia y poder frente a otros partidos o colectivos.

Palabras clave: España; anarquismo; años 30; grupos de afinidad; asociacionismo ácrata; cultura; FAI; Guerra Civil.

\section{[en] The «affinity groups», actors of the anarchistic cultural and societal process} (Spain, 1930-1939)

\begin{abstract}
The objective of this article is to analyze the characteristics and importance of anarchist affinity groups in the thirties within the Spanish libertarian movement. The anarchistic heterodoxy finds in these groups of local area and autonomy of action the way to create a combative and revolutionary militancy. The promotion of culture becomes the central pillar of the intervention of these groups. We will analyze the origin, function, meaning and idiosyncrasy of the basic organizational structure of the Spanish libertarian movement, and how the political changes initiated after the Civil War, would allow the FAI to convert affinity groups into an instrument to achieve greater influence and political power against other parties or groups.
\end{abstract}

Keywords: Spain; anarchism; the thirties; affinity groups; anarchist associationism; culture; FAI; Civil war.

Sumario. Introducción. 1. Los grupos de afinidad durante la República. 2. La Guerra Civil como factor de jerarquización del asociacionismo ácrata. 3. Referencias bibliográficas.

Cómo citar: Lora Medina, A. (2020). "Los «grupos de afinidad», actores del proceso cultural y societario ácrata (España, 1930-1939)”. Cuadernos de Historia Contemporánea, Vol. 42: 215-240.

\section{Introducción}

El carácter militante del anarquismo y la defensa de una moral tan exigente como la ácrata, hace indispensable la vivencia diaria y proselitista del ideal para forjar una

1 Departamento de Historia Contemporánea. Universidad de Sevilla (España)

E-mail: alora@us.es 
hermandad ideológica. Para el movimiento libertario, el individuo no se entiende sin el colectivo, ni éste sin el individuo, de ahí que tan importante es el desarrollo interno de una cultura personal, como la vida en común favorecedora de la cohesión interna necesaria para alcanzar a la sociedad ideal. Para esta compleja mixtura de lo individual y lo colectivo, moralizando las acciones y haciendo que la idiosincracia ácrata permee hacia la superficie de la vida diaria, emerge la figura de los "grupos de afinidad" como elemento central e indispensable de la colectividad anarquista. El carácter societario ácrata permite crear una situación en la que lo comunal representa la suma de las individualidades activas en equilibrio permanente con el bien del colectivo. El individuo que abraza la ideología ácrata busca sentirse útil dentro de un colectivo que posee unas motivaciones filosóficas determinadas y unos fines materiales concretos. La experimentación de la solidaridad interna sirve, de este modo, para fortalecer los lazos de unión de sus miembros formando una hermandad. Estos grupos de afinidad son, en palabras de Enric Ucelay-Da Cal, "una familia alternativa, a la vez círculo estrecho y relaciones progresivamente amplias ${ }^{\text {‘2 }}$. Este vínculo, necesario para construir las bases sobre las que asentar la propaganda libertaria, se fortalece con la implementación de actividades socioculturales que fortalecen la adscripción personal y colectiva a las ideas ácratas, vertebrando un espíritu de confraternidad necesario para respaldar las acciones de lucha sindical y revolucionaria contra el Estado burgués ${ }^{3}$.

Estas agrupaciones no son, sin embargo, ninguna novedad del movimiento anarquista, sino que éstos las asumen como un elemento básico de su confraternidad interna. Los primeros grupos así considerados se retrotraen a finales del siglo XIX, en un ambiente de consolidación del movimiento obrero revolucionario, y van a compaginar su labor pública de propaganda sindical y reivindicativa, con el cultivo de la cultura y la moral ácrata. Estos colectivos, aunque nacidos al margen del anarcosindicalismo protestatario, supo integrarse perfectamente dentro del naciente mundo cenetista hasta convertirse en parte indispensable de su estructura organizativa ${ }^{4}$.

La década de 1920, que iba a estar marcada por la represión del llamado trienio bolchevique, se acentuaría con la clandestinidad de sus militantes tras la ilegalización de la CNT durante la dictadura de Miguel Primo de Rivera. Durante estos años, los grupos, algunos, participaron en la lucha contra el pistolerismo de la patronal, mientras se mantenía la construcción de una contracultura de la autoeducación, con valores filosóficos y estéticos que alentaban el debate didáctico y se extendía la percepción que

2 Ucelay-Da Cal, Enric: "El pueblo contra la clase: populismo legitimador, revoluciones y sustituciones políticas en Cataluña (1936-1939)", Ayer, 50 (2003), pp. 160, 161.

3 Tarrow, Sidney: El poder en movimiento. Los movimientos sociales, la acción colectiva y la política, Madrid, Alianza Editorial, 1997, pp. 44, 45. Razón por la cual las principales figuras del anarcosindicalismo español de los años treinta militaron en alguna de las múltiples agrupaciones existentes. La lista incluye, entre otros, a Francisco Ascaso, Gregorio Jover, Buenaventura Durruti, Aurelio Fernández, Juan García Oliver, Miguel García Vivancos y Ricardo Sanz (Los Solidarios / Nosotros); Joaquín y Domingo Ascaso (Los Indomables); Domingo Torres (Paso a la Verdad), Salvador Cano Carrillo (Ariel), Lola Iturbe y Juan Manuel Molina "Juanel" (Germen), Mauro Bajatierra (Los Iguales) o los hermanos José y Pedro Pellicer (Nosotros).

4 Son grupos, como el formado en 1913 por Paulino Díez en Melilla y cinco compañeros, que se constituyen para la difusión de varias cabeceras de prensa, reparto de folletos de pensadores anarquistas sobre los que tenían una especial consideración o realizar campañas antialcohólicas entre los trabajadores para denunciar los efectos perniciosos del alcohol. Todo ello dependía de la motivación y el esfuerzo personal de sus componentes que tenían que afrontar la propaganda y exposición de su ideal junto a ilegalizaciones, cárcel o muerte de muchos de sus miembros. Díez Martín, Paulino: Memorias de un anarcosindicalista de acción, Barcelona, Bellaterra, 2006, p. 59. 
la revolución social era la única solución a los males de la sociedad. La principal motivación y actividad de estas agrupaciones era impulsar la propaganda en sus pueblos y ciudades a través de conferencias, charlas y debates, el estudio con clases nocturnas, escuelas racionalistas y bibliotecas, y la libre conciencia con la divulgación de publicaciones de prensa, libro y artículos contestatarios. Las actividades se completaban con veladas artísticas o excursiones a la naturaleza que son una exposición variada de la diversidad de actividades impulsadas por el movimiento libertario español ${ }^{5}$.

El más famoso de estos grupos de afinidad es el de Los Solidarios. Estaba formado por jóvenes de 22 a 32 años, que llevaron a cabo, además de asesinatos de personalidades destacadas en venganza por la represión policial, expropiaciones y asaltos de bancos para reunir recursos con los que incentivar la propaganda sindical y ayudar a los presos anarquistas. Su carácter autónomo se demuestra en la forma de elección de sus objetivos, ya que estos eran propuestos tanto por sus miembros -como el intento de regicidio de Alfonso XIII en París a instancia de Durruti y Ascaso; o el asesinato del cardenal Juan Soldevila, a cargo de Torres Escartín, Ascaso y Aurelio Fernández-, como por militantes ajenos al mismo. Sin embargo, dado el carácter de fraternidad igualitaria, la proposición debía ser siempre debatida y votada internamente para valorar su viabilidad, riesgo y efectividad. Así sucedió con la propuesta de atentar contra Mussolini -realizada por Errico Malatesta a través de Orobón Fernández y Schavina- o la enviada por el Comité Nacional de la CNT -entonces liderado por Ángel Pestaña- para la ejecución del general Martínez Anido ${ }^{6}$. Estos atentados tienen el objetivo de vindicar el asesinato de destacados militantes cenetistas - como los de Salvador Seguí, Evelio Boal, Antonio Feliu o Juan Pey-, en una suerte de venganza revolucionaria que persigue desestabilizar la dictadura

\footnotetext{
Solidaridad Obrera (A Coruña), 01-07-1933, p. 1; Tierra y Libertad (Barcelona), 05-09-1931, p. 2; Vega, Eulalia: "Mujeres y militancia en el anarquismo español (1931-1936), Spagna Contemporánea, 40 (2011), pp. 83, 84; Díez, Xavier: "«Amaos y no os multipliquéis». El discurso ético-sexual del anarquismo individualista en Cataluña (1927-1937)", Spagna Contemporánea, 21 (2002), p. 108; Ealham, Chris: La lucha por Barcelona. Clase, cultura y conflicto 1898-1937, Madrid, Alianza Editorial, 2005, pp. 192-195; Cruz Martínez, Rafael: "La cultura regresa al primer plano", en Rafael Cruz Martínez y Manuel Pérez Ledesma (eds.): Cultura y movilización en la España Contemporánea, Madrid, Alianza Editorial, 1997, pp. 15, 16; Navarro Navarro, Francisco Javier: Ateneos y grupos ácratas. Vida y actividad cultural de las asociaciones anarquistas valencianas durante la Segunda República y la Guerra Civil, Valencia, Direcció General del Llibre, Arxius i Biblioteques, 2002, p. 134.

6 Según Juan García Oliver, a principios de los años 20, el Comité Nacional de la CNT le encargó la formación de un grupo anarquista para llevar a cabo dos magnicidios que sacudieran la esfera pública española. Por un lado, la del pretendiente carlista Jaime de Borbón y Borbón-Parma, y, por otro, la del general Severiano Martínez Anido. El encargo, asumido por el grupo "Los Solidarios" con un total de 14 miembros (Eusebio Brau, Alfonso Miguel, García Oliver, Rafael Torres Escartín, Francisco y Alejandro Ascaso, Ricardo Sanz, Miguel García Vivancos, Aurelio Fernández, Gregorio Suberviola, Durruti, Antonio "El Toto", Manuel Campos “Torinto" y Bargutia), además de organizar la salida y la preparación de sendos golpes, se divide en dos para llevar a cabo sus objetivos. Sin embargo, el pretendiente carlista escapa a París y Martínez Anido marcha a San Sebastián, pero al llegar el grupo encargado de asesinarlo éste había desaparecido. Frustrados los atentados, ambos grupos marchan de regreso a Barcelona, pero en el camino, uno se detiene en Zaragoza, donde ejecuta al cardenal Soldevila, mientras el otro hace lo propio con Fernando González Regueral, ex-gobernador civil de Navarra y Bilbao. Ambos asesinatos improvisados son justificados desde la óptica de que eran culpables por haber perseguido y condenado a obreros huelguistas o contratado pistoleros para acabar con la vida de militantes ácratas. Sin embargo, dado que no se habían cumplido los objetivos, García Oliver, siempre según su propio testimonio, es llamado por el Comité Nacional a rendir cuentas por los dos asesinatos no pactados. El anarquista catalán se defendería argumentando que ambos habían sido decisiones espontáneas de "El Toto" y "Torinto", por un lado, y Francisco Ascaso, Torres Escartín y Aurelio Fernández, por otro. García Oliver, Juan: El eco de los pasos. El anarcosindicalismo en la calle, en el Comité de Milicias, en el gobierno, en el exilio, Barcelona, Ruedo Ibérico, 1978, pp. 630-632.
} 
mediante una suerte de "propaganda por el hecho". Sin embargo, la democracia interna se rompía por la propensión de algunos de sus miembros al liderazgo, como sucedería con el grupo Nosotros, surgido de las cenizas de Los Solidarios durante la Segunda República. Algunos de sus miembros originales, como García Vivancos o Alfonso Miguel, se negaron a formar parte de un conjunto en el que componentes como Buenaventura Durruti, es acusado de tener un espíritu demasiado dominante ${ }^{7}$.

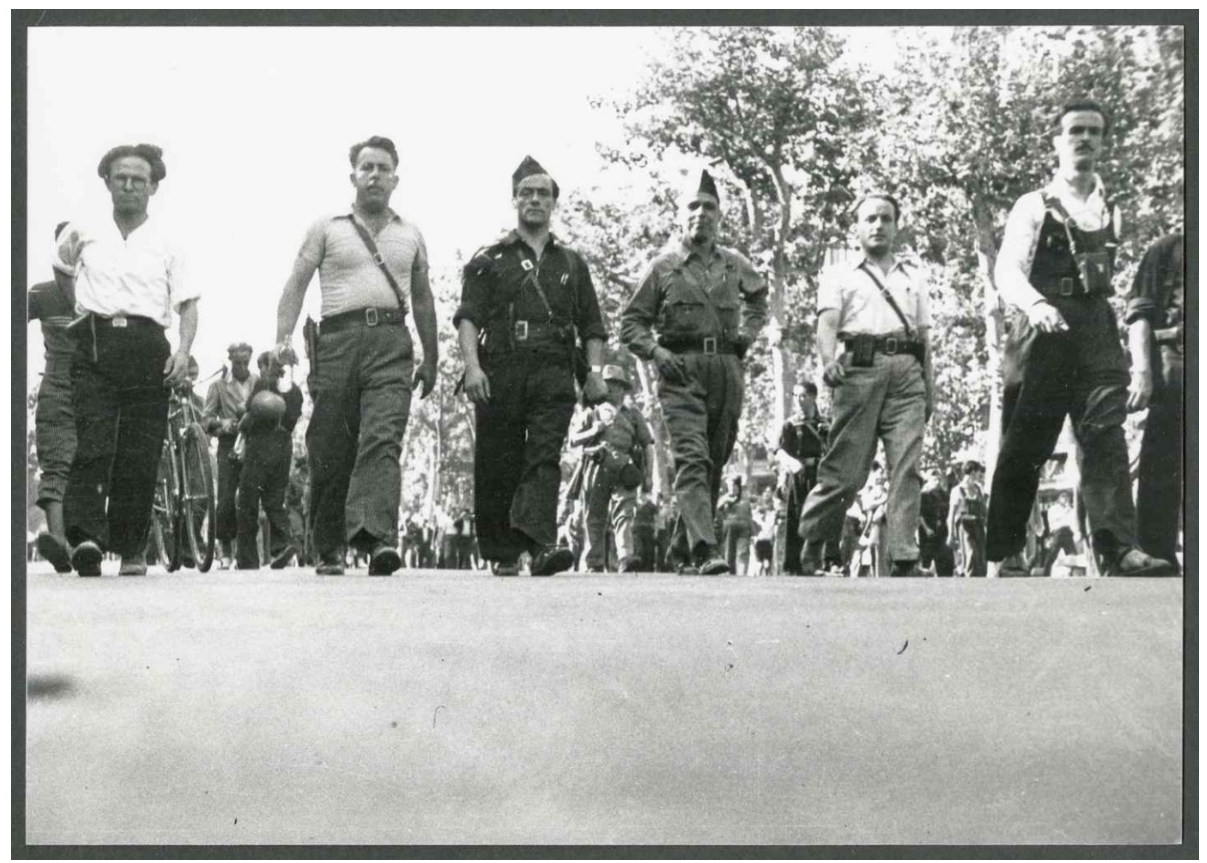

Imagen 1. Fotografía que muestra, de izquierda a derecha, a cuatro de los miembros del grupo Nosotros durante los primeros días de la guerra en Barcelona: Ricardo Sanz (sucesor de Durruti al mando de su Columna y Jefe de la 26 División como teniente-coronel), Juan García Oliver (fue uno de los líderes anarquistas durante la Guerra y Ministro de Justicia bajo la presidencia de Largo Caballero), Gregorio Jover (miembro de la Columna Ascaso y con la militarización de las milicias nombrado teniente-coronel) y Aurelio Fernández (miembro del Comité Central de Milicias Antifascistas de Cataluña junto a García Oliver y Consejero de Sanidad y Asistencia Social de la Generalidad de Cataluña. International Institute of Social History de Ámsterdam (IISH).

La caída de la monarquía y la instauración de la República en 1931 devuelve a la legalidad el asociacionismo anarquista con gran número de afiliados, demostrando que los años de clandestinidad no le afectaron negativamente. Con el nuevo panorama político iban a surgir y proliferar nuevas agrupaciones libertarias que encaran la defensa del ideal

García Oliver, Juan: El eco de los pasos. El anarcosindicalismo en la calle, en el Comité de Milicias, en el gobierno, en el exilio, Barcelona, Ruedo Ibérico, 1978, pp. 93, 630-632; De Rol, Valentín: Ascaso, Durruti, Jover. Su obra de militantes. Su vida de perseguidos, Buenos Aires, Ediciones del Semanario Anarquista La Antorcha, 1927; Ealham, Chris: La lucha por Barcelona..., pp. 99, 100; González Fernández, Ángeles: Utopía y realidad. Anarquismo, anarcosindicalismo y organizaciones obreras: Sevilla, 1900-1923, Sevilla, Diputación Provincial de Sevilla, 1996, pp. 86-88. 
anarquista centrando toda su labor en la implementación de actividades culturales y de acción directa. Sin embargo, la independencia casi absoluta de los grupos de afinidad durante los años $20 \mathrm{iba}$ a ser poco a poco matizada durante la década posterior para tender a cierto centralismo que será especialmente evidente durante los años de la Guerra Civil. En este sentido, fue clave la fundación de la Federación Anarquista Ibérica (FAI) en 1927, ya que nacía una nueva estructura organizativa que favorecería el nacimiento de federaciones de distinto ámbito (local, regional y nacional), que fueron fundamentales en la vertebración de un amplio conglomerado social que hasta entonces existía esparcido sin orden aparente. Sin embargo, aunque la "Específica" no nacía para ejercer un papel rector sobre el resto de agrupaciones libertarias, despertó cierto miedo y recelos tanto dentro del mundo anarcosindicalista -una de las críticas, como la realizada por Gaston Leval, fue acusar a la FAI de querer implantar una "semi-dictadura"-, como fuera de él - es vista por algunos sectores como una organización que persigue extender el terror y la violencia-. En contraposición, sectores afines a ella como el clan de los Montseny, defendería públicamente la necesidad de un organismo específicamente anarquista y separado del sindicato, condenando además la criminalización de la que estaba siendo objeto":

Aunque os parezca mentira la F.A.I. se ha convertido en la Cenicienta de la política española. Cuando no se sabe a quién cargar la culpa de algo, se carga a la F.A.I. Que se produce un pedrisco que diezma los campos y sume en la miseria [...] a miles de familias españolas: la F.A.I. tiene la culpa. Que una nube de langosta asuela los pueblos [...]: la F.A.I. tiene la culpa. Que unos señores encaramados en el Poder en determinada región de España deciden cometer una torpeza política y se enredan en una lucha a cañonazos con los representantes del Poder central, lo que les lleva al banquillo de los acusados: la F.A.I. tiene la culpa. Incluso se llega a la ingenuidad de decir que los cañonazos era la F.AI. quien los disparaba, o que los otros creían que la F.A.I., etc. etc. [...] La F.A.I. es una entelequia, una abstracción, una sombra, un fantasma, un nombre o un espíritu. Sea lo que fuere, la F.A.I. resulta una excusa magnífica para explicarlo todo ${ }^{10}$.

El éxito del discurso de la FAI y su afán por extender la gimnasia revolucionaria se debe a que el discurso moderado de la contención y el afianzamiento de las conquistas sociales no acababa de encontrar una mayoría suficiente. La tragedia de Casas Viejas marca un camino sin retorno hacia posiciones rupturistas que pretenden acelerar la revolución; de ahí que anarquistas que no pertenecen inicialmente a ésta -como García Oliver, Durruti o Ascaso, entre otros-, sean identificados públicamente con ella por la defensa de una posición maximalista dentro de la CNT. Razón por la cual, y siempre

8 Albiñana, Antonio, Arancibia, Mercedes: "La última entrevista con Gaston Leval", Tiempo de Historia, 46 (1978), p. 17.

9 Navarro Navarro, Francisco Javier: Ateneos y grupos ácratas..., p. 77; Bookchin, Murray: Los anarquistas españoles..., pp. 271, 272; Christie, Stuart: ¡Nosotros, los anarquistas!: un estudio de la Federación Anarquista Ibérica (FAI), 1927-1937, Valencia, Universitat de València, 2010; Elorza, Antonio: "Hace ahora cincuenta años: la fundación de la F.A.I.!", Tiempo de Historia, 33 (1977), pp. 4-21; Vadillo Muñoz, Julián: “Desarrollo y debates en los grupos anarquistas de la FAI en el Madrid republicano", Germinal, 4 (2007), pp. 27-65; Garner, Jason: "La búsqueda de la unidad anarquista: la Federación Anarquista Ibérica antes de la II República", Germinal, 6 (2008), pp. 49-79; Bernecker, Walther: "Acción directa y violencia en el anarquismo español”, Ayer, 13 (1994), pp. 147-188; Mintz, Frank: Autogestión y anarcosindicalismo en la España revolucionaria, Buenos Aires, Ed. Terramar, 2009; Saña, Heleno: La revolución libertaria. Los anarquistas en la Guerra Civil Española, Pamplona, Ed. Laetoli, 2010, p. 33.

$10 \quad$ La Revista Blanca (Barcelona), 07/06/1935, p. 522. 
después de los sucesos mencionados cuando, parte de los antiguos miembros de Los Solidarios acabarían ingresando en la FAI con el nombre de Nosotros. En el fondo, no se trató de que la FAI controlara a la CNT, sino que buena parte de los militantes cenetistas se sintieron más identificados con los postulados defendidos por la primera, ya que ofrecía una solución rápida a los problemas del paro, el hambre y la pobreza, que los discursos de contención apoyados por otros sectores más moderados de la CNT -como Ángel Pestaña, Juan López, Juan Peiró o Ricardo Fornells_- ${ }^{11}$.

Los grupos de afinidad actúan como, un mecanismo de cohesión interna que fomenta el compañerismo y a través de sus experiencias vitales se conforma una relación igualitarista en el que los lazos personales priman sobre la valía personal y el puritanismo ácrata. En esta línea, cuando Melchor Rodríguez es designado delegado general de prisiones en noviembre de 1936 en un Madrid asediado, se ayudará de algunos de los miembros de su antiguo grupo de Los Libertos para asegurarse el control del sistema penitenciario madrileño. Este fomento del amiguismo se acaba convirtiendo en norma e iba a sancionar una especie de "clientelismo" libertario en el que algunas de estas agrupaciones intentarán controlar, a partir de su propio grupo, la organización sindical desde la nueva estructura de la FAI. Esta realidad se evidencia, por ejemplo, en el hecho de que la mayoría de los miembros de Los Solidarios/Nosotros alcanzaran puestos de relevancia durante los primeros meses del inicio de la guerra: Juan García Oliver y Aurelio Fernández participaron conjuntamente en el Comité de Milicias Antifascistas de Cataluña; Antonio Martínez "Valencia" fue encargado de la escolta personal de su amigo García Oliver; Buenaventura Durruti estuvo al mando de una columna miliciana que llevaba su nombre; García Vivancos comandaba la columna "Los Aguiluchos"; Gregorio Jover lideraba la columna "Ascaso"; Antonio Ortiz capitaneaba la columna "Roja y Negra"; y Ricardo Sanz sería nombrado sucesor de Durruti al frente de su columna en Aragón. Sin embargo, las disputas internas entre grupos conduce a que la autoridad moral que durante los años treinta poseía el grupo Nosotros -que llegó a controlar en la práctica el Comité Regional de la CNT catalana a mediados de 1930- le fuera disputada por otras agrupaciones recién formadas como Nervio (Diego Abad de Santillán y Pedro Herrera), A. (Jacinto Toryho, Alfredo Martínez y Abelardo Iglesias) o Afinidad (José Peirats, Pedro Conejero y Ginés Alonso) ${ }^{12}$.

\section{Los grupos de afinidad durante la Segunda República}

Durante la Segunda República, y bajo la égida de la FAI, los grupos de afinidad están conformados por pequeños núcleos de militantes que se unen por similitudes ideológicas o por amistad personal. La prensa se convierte en el medio predilecto para informar a la militancia sobre la formación, procedencia y ubicación de nuevos grupos o la realización de todo tipo de actividades. Sus páginas también sirven para solicitar, en práctica del apoyo mutuo y la solidaridad obrera, desde materiales de propaganda (libros, folletos

11 García Oliver, Juan: El eco de los pasos..., pp. 120-124, 127; Ruipérez, María, Pérez Ledesma, Manuel: “José Peirats, la C.N.T. y la revolución social", Tiempo de Historia, 62 (1980), p. 44.

12 García Oliver, Juan: El eco de los pasos..., p. 135; Domingo Álvaro, Alfonso: "Melchor Rodríguez y los Libertos", Germinal, 6 (2008), p. 81; Tavera, Susana, Ucelay-Da Cal, Enric: "Grupos de afinidad, disciplina bélica y periodismo libertario, 1936-1938”, Historia Contemporánea, 9 (1993), pp. 167, 173; Ealham, Chris: La lucha por Barcelona..., pp. 99, 100; Bookchin, Murray: Los anarquistas españoles: los años heroicos 1868-1936, Valencia, Ed. Numa, 2000, pp. 271, 272. 
o revistas) hasta explicar cuál era el motivo que había llevado a sus miembros a fundar un nuevo grupo anarquista. No es de extrañar que durante estos años, Tierra y Libertad, portavoz del faísmo, destacara por ser la principal cabecera de información sobre todo lo que acontecía a estas células que conformaban el conglomerado básico del anarcosindicalismo español. También eran continuas las llamadas a aunar esfuerzos y en un pueblo o ciudad entre distintos grupos; así harían Los Simpatria de Ceuta, solicitaban establecer contacto con otros colectivos cercanos para llevar a cabo acciones comunes de propaganda. Esta interrelación grupal aumenta en las grandes ciudades en la que éstos se repartían sus zonas de influencia por barrios o distritos ${ }^{13}$.

Incluso, los propios grupos realizaban llamamientos a través de la prensa para que militantes sin grupo se animaran y fundaran nuevos colectivos con los que ahondar en la propaganda libertaria y captar nuevos seguidores. Ello demuestra que la atomización grupal era perseguida por los propios anarquistas, y se preferían grupos pequeños en los que las relaciones fueran mucho más personales, a grupos grandes en los que sus miembros no se conocieran bien:

Joven compañero: en tu barrio o pueblo contarás con dos, ocho, quince o más amigos que te sean afines en ideales emancipadores o naturistas. Reuníos y constituid una agrupación. Ponedle un nombre y encargad un sello que os sirva de firma colectiva. Poneos en comunicación con otros grupos afines. Suscribíos a periódicos que os iluminen. Formad una biblioteca, leyendo individual o colectivamente sus libros. Propagad a los cuatro vientos vuestros ideales de regeneración y emancipación humana por medio de la tribuna, el periódico, la hoja o el manifiesto [...]"14.

La constitución de nuevos colectivos se oficializaba con la celebración de una asamblea a la que acudían todos sus miembros, como la celebrada en octubre de 1936 en el local del Sindicato Único de las Artes Gráficas de Barcelona para la inauguración de Los de Ayer y los de Hoy. Durante la misma, se nombraba la junta directora y se aprobaban los estatutos internos, comprometiéndose todos sus miembros a extender la cultura y a luchar por destruir el "mundo oficial, religioso y capitalista que acabará debido a nuestra constancia y buena voluntad"15. Aunque resulta difícil

13 El caso más significativo fue el de Barcelona, cuyo elevado número de militantes permitía la coexistencia de numerosos grupos de afinidad. De este modo, Rebelión y el Grupo Cultural Estudios actuaban en la barriada de Poblenou; Ideas y Luz en el Clot; Paso a la Verdad, Natura y Floreal en Sans; Juventud Libertaria en la Barceloneta; Amor y Voluntad en San Martín y Vencer o Morir en Sarriá. Esta multiplicidad asociativa tenía su origen en la expansión industrial y poblacional de la ciudad décadas atrás que había producido una separación del paisaje urbano con la proliferación de barrios obreros como el Poblenou, el Raval, Sants o la Barceloneta. La confluencia de tantos colectivos se hizo especialmente notoria a finales de la década, llegando en 1937 a converger hasta un total de 25 agrupaciones -Acracia, Neno Vasco, Semilla Libertaria, Los Luchadores del Ideal, Los Unos, Tomás Herreros, Los Constantes, Los Analfabetos, Los que no Claudican, Velis Nolis, Braulio, Fosco Falsachi, Los Invisibles, Los Electrons, Los Vengadores, Temple y Rebeldia, Adelante Ferroviarios, Hacia el Porvenir, Nadie, Errico Malatesta, Gori, Los Sinceros, C, Germen y Generación Consciente-. Solidaridad Obrera (Barcelona), 23-04-1937, p. 10; Tierra y Libertad (Barcelona), 05-06-1936, p. 3; Tierra y Libertad (Barcelona), 08-05-1936; Solidaridad Proletaria (Sevilla), 14-11-1931; Tierra y Libertad (Barcelona), 05-09-1931, p. 2; Solidaridad Obrera (Barcelona), 10-10-1936, p. 7; Tierra y Libertad (Barcelona), 01-07-1932, p. 2; Tierra y Libertad (Barcelona), 17-04-1936, p. 3; Tierra y Libertad (Barcelona), 2907-1932, p. 2; Tierra y Libertad (Barcelona), 05-07-1935, p. 1; La Revista Blanca (Barcelona), 03-04-1936, p. 3; Solidaridad Obrera (Barcelona), 16-10-1936, p. 10; Ealham, Chris: La lucha por Barcelona..., pp. 64-79; Oyón, José Luis: "La ruptura de la ciudad obrera y popular: espacio urbano, inmigración y anarquismo en la Barcelona de entreguerras, 1914-1936", Historia Social, 58 (2007), pp. 123-150.

14 Antorcha (Las Palmas), 01-05-1936, p. 4.

15 Tierra y Libertad (Barcelona), 08-10-1936, p. 7. 
establecer una cifra aproximada del total de grupos anarquistas activos durante la década, un análisis pormenorizado de la prensa consultada nos permite arrojar la cifra nada desdeñable de un total mínimo de 785 grupos, de los cuáles 673 serían de nueva creación durante los años treinta ${ }^{16}$.

Este exorbitante crecimiento remite, por un lado, a uno de los problemas más habituales con los que tienen que lidiar estas agrupaciones. Se trata de la temporalidad y las altas probabilidades de disolución de los mismos debido a motivos tan diversos como la emigración, la cárcel, la enfermedad, la guerra o la muerte. Este fue el caso del grupo Luz en la Densa Obscuridad de Olvera (Cádiz) formado por ocho miembros que se había tenido que disolver durante el verano de 1936 a causa del conflicto bélico. Al final, reencontrados en Málaga siete de sus ocho componentes, decidieron volver a la actividad con el nombre de uno de sus compañeros muerto en combate; así nacía el grupo López Usagre ${ }^{17}$. Y, por otro lado, al hecho de constituirse como pequeñas células les permitía funcionar con rapidez al estar compuestos por pocos individuos y no necesitar grandes infraestructuras para funcionar.

Gráfico I. Distribución por año de los grupos de afinidad creados entre 1930 y 1938 en España.

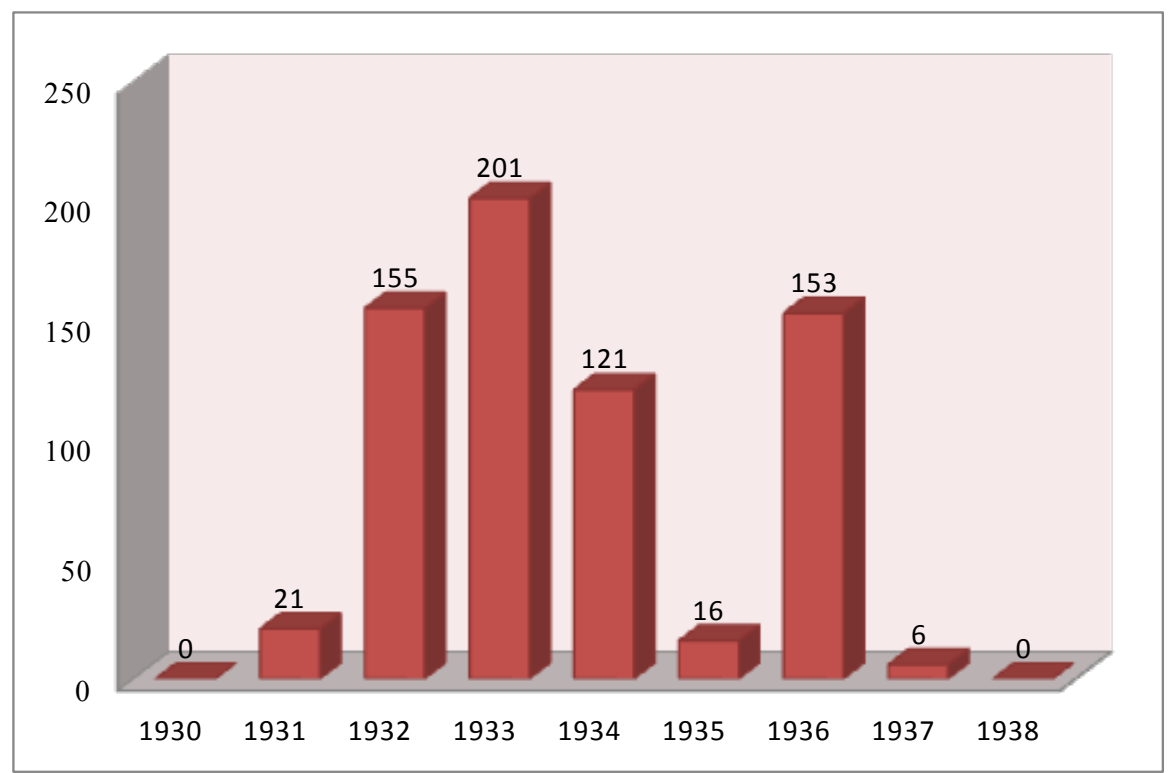

Imagen 1. Elaboración propia basada en la consulta de la prensa anarcosindicalista para el periodo 1930-1938.

16 Las cifras aportadas están por debajo de los datos facilitados por Albert Balcells, ya que en el pleno de la FAI celebrado en Madrid en octubre de 1933 estuvieron representados un total de 569 grupos, a los que habría que sumar otros 632 que mandaron su adhesión escrita. Esto se debe a que las cifras aportadas desde la prensa ácrata sean cifras mínimas ya que la pérdida o destrucción de parte de las fuentes hemerográficas necesarias para completar los datos impide que estos sean totales. Balcells, Albert: Crisis económica y agitación social en Cataluña de 1930 a 1936, Barcelona, Ed. Ariel, 1971, p. 196.

17 Tierra y Libertad (Barcelona), 21-11-1936, p. 7; Navarro Navarro, Francisco Javier: Ateneos y grupos ácratas..., pp. 76-81; Martín Nieto, Isaac: “Anarcosindicalismo, resistencia y grupos de afinidad. La comisión de propaganda confederal anarquista (1937-1939)”, El Futuro del Pasado, 1 (2010), p. 598. 
En el gráfico I se observa cómo el surgimiento de nuevas agrupaciones está directamente relacionado e influido con el gobierno que se encuentra en el poder ese año, la represión existente o no contra la CNT-FAI y la conflictividad social que permea toda la década. El primer bienio republicano (1931-1933), marcado por el entusiasmo popular de un nuevo sistema y la proclamación de una Constitución que definía a España como "una República de trabajadores", supuso el marco ideal en el que la propaganda ácrata alcanzaría su máxima expresión consiguiendo grandes resultados en la movilización de su militancia. La esperanza y la reserva de la militancia cenetista en la capacidad transformadora del nuevo sistema se mantuvo durante los primeros meses de República, hasta que las sucesivas medidas del gobierno en materia laboral y sindical fueron alejando la ilusión inicial, marcada por la legalización de la CNT y la instauración de una serie de derechos individuales y colectivos que habían favorecido la enorme proliferación del asociacionismo ácrata. Durante este periodo se crearon como mínimo 377 agrupaciones de afinidad, siendo el año 1933 (con 201), el de la víspera del cambio de gobierno y el de la abstención anarquista en las elecciones como consecuencia de los Sucesos de Casas Viejas, el de mayor profusión asociativa libertaria. Esto demuestra que la política reivindicadora de la CNT, las huelgas generales y las insurrecciones anarquistas no dispersó la militancia ni la disminuyó, sino todo lo contrario, debido en buena medida a una radicalización de la CNT que aumentó su tendencia propiamente anarquista, dándole cada vez más eco en su interior a la FAI.

En el siguiente bienio, marcado por el cambio de gobierno a favor de los radicales de Lerroux con el apoyo de la derecha de Gil Robles, y la división en la izquierda parlamentaria, encontramos una doble realidad. En primer lugar, que 1934 mantiene la estela de los dos años anteriores y está directamente influido por la fallida huelga general revolucionaria que acabaría desembocando en la Revolución de Octubre en Asturias. Ese hito supuso el inicio de la represión institucional de partidos y sindicatos (que en el caso de la CNT habría que retrotraer a la fallida insurrección anarquista de diciembre de 1933), lo que tuvo su reflejo evidente en la creación de nuevos colectivos ácratas, reduciéndose estos a cifras casi inexistentes (16). Y, en segundo lugar, 1936, con la celebración de nuevas elecciones, el nacimiento del Frente Popular, el apoyo tácito del anarcosindicalismo español al nuevo gobierno y el fracaso del golpe de estado del 18 de julio, marcarían un nuevo periodo de revitalización del asociacionismo ácrata como consecuencia de un aumento de la propaganda y de la creencia de la inminente cercanía de la revolución social (152 grupos). Sin embargo, el enorme repunte vivido en 1936 iba a tener su cruz al año siguiente, en el que las cifras no solo no se mantendrían, sino que bajaron a guarismos de 1931 o 1935. Esto se explica por el inicio de la guerra, la dispersión de los militantes y la muerte de muchos de ellos, la división del país en dos bandos y, también, por la centralización impulsada dentro del movimiento anarquista que afectó especialmente a la razón de ser de los grupos de afinidad, y que los redujo exponencialmente para hacerlos más grandes y masivos ${ }^{18}$.

18 Villa García, Roberto: “«Obreros, no votéis». La CNT y el Frente Popular en las elecciones de 1936”, Pasado y Memoria, 13 (2014), p. 174; Caro, Diego: "El anarcosindicalismo y la victoria del Frente Popular", Historia Social, 76 (2013), pp. 54-66; Villa García, Roberto: La República en las urnas, Madrid, Marcial Pons, 2011, pp. $269-274$. 
Gráfico II. Distribución de los grupos de afinidad creados en la década de los años 30 en relación a la división regional de la CNT.

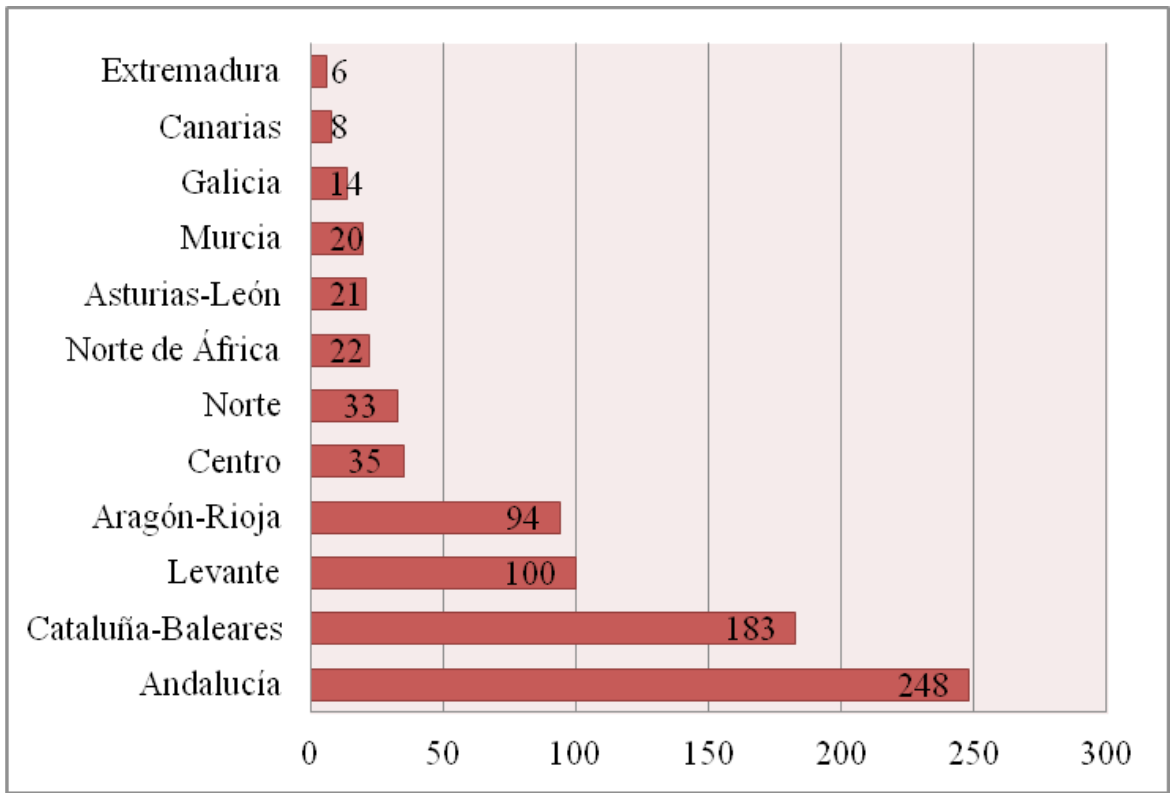

Imagen 1. Elaboración propia basada en la consulta de la prensa ácrata para el periodo 1930-1938.

Respecto a la distribución territorial de los grupos de afinidad creados durante la década, la mayoría se concentran en los ejes Andalucía y Cataluña/Baleares. Esto evidencia, no ya la existencia de un mayor predicamento de las ideas ácratas en estos territorios, sino la excesiva polarización de la afiliación en estas dos regiones clásicas del anarquismo y la debilidad estructural que padece el movimiento en otros territorios, incluso en tiempos de máxima difusión del ideal ácrata como fueron los años treinta. En la zona catalana y a nivel nacional, Barcelona es la provincia con mayor número de agrupaciones, con hasta 149 grupos durante toda la década lo que la convierte en la plaza fuerte del anarquismo hispano y la urbe de referencia para muchos trabajadores. Esto se debe no sólo porque Girona, Tarragona y Lleida tuvieran porcentajes ínfimos en comparación con la Ciudad Condal, sino porque condensa un enorme volumen de población tanto autóctona como foránea. Por otro lado, la mayor presencia cuantitativa del asociacionismo ácrata se concentra en Andalucía, especialmente en su parte Occidental; principalmente en la zona de la depresión del Guadalquivir y la fachada marítima del litoral gaditano con especial importancia de las provincias de Cádiz y Sevilla -con 72 y 56 grupos respectivamente-. Esta aparente fortaleza numérica de esta región, a diferencia de lo sucedido en la zona catalana, no tuvo una plasmación real durante la Guerra Civil ${ }^{19}$.

19 Esta realidad del anarquismo andaluz se debió, en buena medida, a su incapacidad por consolidar una organización campesina anarquista que aglutinara a todo el campesinado andaluz, así como a las disensiones internas en el seno de la CNT andaluza (que llevó a que destacadas figuras como Sánchez Rosa o Pedro Vallina fueran apartados de sus respectivos sindicatos), afectaron gravemente a un movimiento que con el estallido de la Guerra Civil se descompuso sin ser capaz de ofrecer cierta resistencia para frenar a los sublevados. Villa García, Roberto: La República en las urnas, p. 82; Maurice, Jacques: El anarquismo andaluz, Barcelona, Ed. Crítica, 1990, 
Levante y Aragón se consolidan como las regiones secundarias en cuanto al surgimiento de nuevas agrupaciones, esto evidencia que el éxito cenetista en estas regiones durante la Guerra Civil viene respaldado por un movimiento asociativo ácrata que arranca a principios de la década. La presencia cenetista en Aragón, según Pere Gabriel, está auspiciada por militantes barceloneses cuya labor de propaganda es notable, no sólo por su cercanía territorial, sino especialmente por la relación entre las distintas estructuras de la CNT ya desde la década anterior. Esta influencia mutua explica que las cúpulas dirigentes de la regional catalana estuvieran formadas por catalanes, andaluces y aragoneses. Al tiempo que, en el surgimiento del Consejo de Defensa de Aragón, fue fundamental la presencia de las milicias anarquistas catalanas en la región, contando además con la influencia de militantes como Joaquín Ascaso, de larga trayectoria en la CNT catalana. Mientras, en la zona levantina destacó especialmente la aparición de cabeceras de diversas corrientes del anarquismo (anarquista, anarcosindicalista, anarcoindividualista y naturista) que reflejan la diversidad doctrinal ácrata: Generación Consciente, Estudios, Orto, Helios, Ética y Nosotros ${ }^{20}$.

En contraposición, se constata la debilidad estructural del asociacionismo ácrata en regionales como Asturias-León, Galicia o Extremadura, en las que la CNT no había conseguido convertirse en la organización principal del mundo obrero local, más ligado a una pequeña o mediana propiedad que, aunque no influye directamente en su orientación sindical o política, es en la práctica un obstáculo más para convertirse en fuerza hegemónica y poder competir con las fuerzas socialistas del PSOE o la UGT por el predominio social. En el Centro y el Norte del país existe una militancia significativa que, aunque no puede pugnar numéricamente con la UGT, determina la existencia de un discurso en el que destacan los casos madrileño y vasco. A pesar de la falta de afiliados, sobresalen militantes ligados tanto a la acción sindical -Cipriano Mera, Teodoro Mora, Feliciano Benito, Horacio Martínez Prieto y David Antona- como a la propaganda cultural y al fomento de la educación y la moral libertaria -Isaac Puente, Lucía Sánchez Saornil, Federica Montseny, Antonia Maymón y Mauro Bajatierra- que favorecerán notablemente la proliferación de agrupaciones libertarias ${ }^{21}$.

En relación a la cuestión de género, y a pesar del discurso favorable a la igualdad de sexos, la composición de los grupos sigue siendo, conforme a épocas anteriores, mayoritariamente masculina y dominante frente a la presencia reducida y secundaria de mujeres. La militancia femenina tuvo que demostrar con su dedicación y esfuerzo que eran igual de aptas que cualquiera de sus compañeros, e intentar callar las voces de muchos hombres cuya doble moral no las acababa de considerar al mismo nivel. Concha Pérez Collado o Sara Berenguer denunciaron la existencia de situaciones

pp. 233-309. La Federación Local de la CNT de Sevilla pasó de 11.750 afiliados en 1931 a algo más de 2.100 en 1936, y lo mismo sucedería en otras provincias como Córdoba, que de 6.110 pasaría a 2.142 en vísperas de la Guerra Civil. Cobo Romero, Francisco, Ortega López, Teresa: Franquismo y posguerra en Andalucía Oriental. Represión, castigo a los vencidos y apoyos sociales al régimen franquista, 1936-1950, Granada, Universidad de Granada, 2005, pp. 39-45.

20 Gabriel Sirvent, Pere: "Propagandistas confederales entre el sindicato y el anarquismo. La construcción barcelonesa de la CNT en Cataluña, Aragón, País Valenciano y Baleares”, Ayer, 45 (2002), pp. 106, 132-134, $139,140$.

21 Vadillo Muñoz, Julián: "Desarrollo y debates en los grupos...”, p. 33; Domingo Álvaro, Alfonso: "Melchor Rodríguez y los Libertos...”, p 82; Barrio Alonso, Ángeles: Anarquismo en Asturias: 1890-1936, Cantabria, Universidad de Cantabria, 1986, pp. 381-503.

Berenguer, Sara: Entre el sol y la tormenta: treinta y dos meses de guerra (1936-1939), Barcelona, Seuba, 1984 , pp. 20-34, 114-117 
como la mofa o el desdén de muchos varones que no entendían que una mujer pudiera dar sola una charla o tuviera opinión propia y formada. Esta ausencia de comportamientos igualitarios, incluso en las propias Juventudes Libertarias, impedía en la práctica una mayor presencia femenina en las estructuras libertarias, lo que afectaba a la credibilidad de que la emancipación debía ser responsabilidad conjunta de hombres y mujeres. Un análisis cualitativo de las distintas agrupaciones refleja, sin embargo, el triunfo parcial del discurso que haría célebre a Mujeres Libres durante la Guerra Civil: la emancipación de la mujer debía ser obra de la propia mujer. Este hecho se muestra en la existencia de grupos de afinidad específicamente femeninos que abogaban por capacitar a la mujer y defender su igualdad con el hombre. En total, se han identificado un total de 16 grupos $^{22}$, cantidad nada desdeñable dada la escasa presencia de mujeres en sindicatos y órganos de participación anarquistas (que oscilaba entre el 15-20\% durante toda la década), y que demuestra que Mujeres Libres no fue un caso aislado de movilización exclusivamente femenina dentro de la estructura ácrata. Dicha novedad reside en la creación de una organización de carácter supranacional por y para las mujeres anarquistas ${ }^{23}$.

La politización de la juventud es una realidad que se extiende a todos los colectivos, partidos y sindicatos de la época y a la que no fue ajena la CNT, de ahí que los jóvenes fueran objeto directo de las atenciones de la prensa libertaria, siendo descritos como verdaderos entusiastas del ideal ácrata. Esta realidad sirve para estimular el crecimiento del asociacionismo juvenil, iniciado ya durante los primeros años del siglo XX, alcanzando su culmen durante la Segunda República; no es hasta 1930 cuando se crea la Federación Ibérica de Juventudes Libertarias. La presencia de los jóvenes en grupos de afinidad es también una realidad bastante extendida, llegando a disponer incluso de agrupaciones propias formadas y dirigidas exclusivamente por ellos. Son colectivos que, al igual que los de adultos, nacen con la impronta de propagar las ideas libertarias y defender los principios de la FAI, así como luchar, como destaca el grupo Luz en la densa obscuridad de Olvera (Cádiz), tanto con el libro como con el fusil para implantar el comunismo libertario. La función principal que les va a caracterizar es la de propagar la enseñanza racionalista y fomentar la

22 Se trata de los grupos: Feminidad Rebelde de Tarrasa (1932), Amor y Armonía de Casas Viejas (1932), Fémina Ácrata de Logroño (1932), Sol Ácrata de Suria (1933), Los Invisibles de Cádiz (1933), el Grupo Femenino de Cultura Social de Tarragona (1933), Las Rebeldes del Pirineo de Pobla de Lillet (1933), Rojo y Negro de Mislata (1933), el Grupo Femenino Libertario de Santander (1933), la Agrupación Femenina Anticlerical Flor de Primavera de Onteniente (1933), Armonía de Córdoba (1934), Vanguardia Libertaria de A Coruña (1934), el Grupo Femenino Juvenil Libertario de Madrid (1935), el Grupo Femenino de Ferrol (1936), Flores que Nacen de Huesca (1936) y el Grupo Femenino del Ateneo Amigos del Libro de Tarrasa. La mayoría de estas agrupaciones estaban adheridas tanto a la FAI como a la FIJL, revelando que se trata principalmente de colectivos formadas por jóvenes.

23 Moroni, Sara: "Concha Pérez Collado", Germinal, 5 (2008), p. 101; Berenguer, Sara: Entre el sol y la tormenta: treinta y dos meses de guerra (1936-1939), Barcelona, Seuba, 1984, pp. 20-34, 114-117; Aguado, Ana, Sanfeliu, Luz: "Juventud, socialismo y compromiso político femenino: entre el asociacionismo y la militancia (19061931)", Ayer, 100 (2015), pp. 47-72; Cases Sola, Adriana: "Mujeres rebeldes. Género, juventud y violencia política en la Segunda República”, Ayer, 100 (2015), p. 79; Santamaría, Jesús: “Juventudes Libertarias y Guerra Civil (1936-1939)”, Studia histórica. Historia contemporánea, 1 (1983), pp. 215-222; Nash, Mary: Mujer y movimiento obrero en España, Barcelona, Ed. Fontamara, 1981, pp. 93, 94; López Santamaría, Jesús: "El desafío de la «Trinidad Libertaria»: Feminismo y afeminismo en el seno del anarquismo hispano. El caso de las JJLL", en Las mujeres y la Guerra Civil Española, Madrid, Ministerio del Trabajo e Inmigración-Instituto de la Mujer, 1991, pp. 88-96. 
educación entre sus miembros, siendo habituales las llamadas en la prensa pidiendo el envío de libros y folletos para la creación de una biblioteca propia ${ }^{24}$.

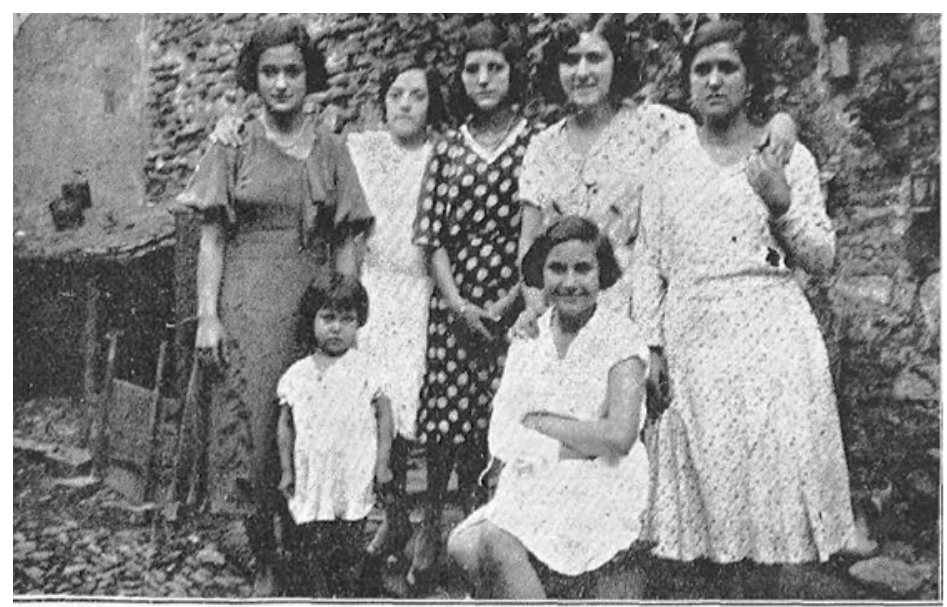

UN BELLO RAMILLETE

Contemplad el grupo de compañeritas que componen la Juventud Femenina Libertaria de Málaga. No están todas las que son, ni son todas las que están. Decimos esto, porque hay aquí tha pequeña anerquista extremadanente joven para ser encasillade en un grupo. No obstante, su actitud decidida, junto a la no menos resuelta de sus amiguitas mayores, da derecho a suponer que, con el tiempo, sevá tua de las más esíorźadas campeonas de Acracia.

Imagen 2. Fotografía que muestra a un grupo de mujeres y niñas pertenecientes a la Juventud Libertaria de Málaga en agosto de 1933. La Revista Blanca (Barcelona), 01-081933, p. 143.

Esta relación tan estrecha de las agrupaciones juveniles con el estudio y con la filosofía anarquista hace que entre estas abunden, incluso con mayor frecuencia que en los grupos de adultos, las denominaciones con referencia a anarquistas destacados, tanto a nivel nacional -Salvochea o Ferrer y Guardia- como internacional -Bakunin, Malatesta o Pedro Gori-. Nombres elegidos atendiendo a razones concretas, nunca al azar, ya que reflejan la impronta que dicho colectivo quiere darle a su grupo. Tras la denominación de Ferrer y Guardia, además de la apología de la educación como vehículo formador de conciencias, y Pedro Gori subyace la crítica al Estado como ente represor del ideal anarquista. En los casos de Bakunin, Salvochea o Malatesta se distingue la defensa de la acción social como motor del cambio y un carácter de rebeldía y combatividad para la movilización revolucionaria. Otras agrupaciones hacían referencia a elementos que se consideraban característicos de la juventud anarquista, como un temperamento social díscolo, desobediente y hostil ante el status quo establecido (grupos como Los Rebeldes, Juventud Rebelde, Los Verdaderos o Redención). En total, se han contabilizado un mínimo de 212 agrupaciones juveniles

24 Souto Krustín, Sandra: "Introducción: juventud e historia”, Hispania, 67/225 (2007), p. 14; González Calleja, Eduardo, Souto Kustrín, Sandra: "De la dictadura a la República: orígenes y auge de los movimientos juveniles en España”, Hispania, 67/225 (2007), pp. 73-102; González Calleja, Eduardo: "Introducción”, Ayer, 59 (2005), pp. 11-19; Tavera, Susana: "Escola de rebel.lia. La joventud i 1'anarcosindicalisme", en Enric Ucelay-Da Cal: La joventud a Catalunya al segle XX. Materiales per a una historia, Barcelona, Diputació de Barcelona, 1987, vol. I, pp. 138-151; Solidaridad Obrera (A Coruña), 21-03-1931, p. 3; Tierra y Libertad (Barcelona), 19-081932; Tierra y Libertad (Barcelona), 21-11-1936, p. 7. 
para toda la década; número que demuestra la importancia que habían adquirido estos colectivos dentro del organigrama societario ácrata ${ }^{25}$.

Gráfico III. Distribución de los grupos de afinidad de jóvenes en función de la división regional de la CNT.

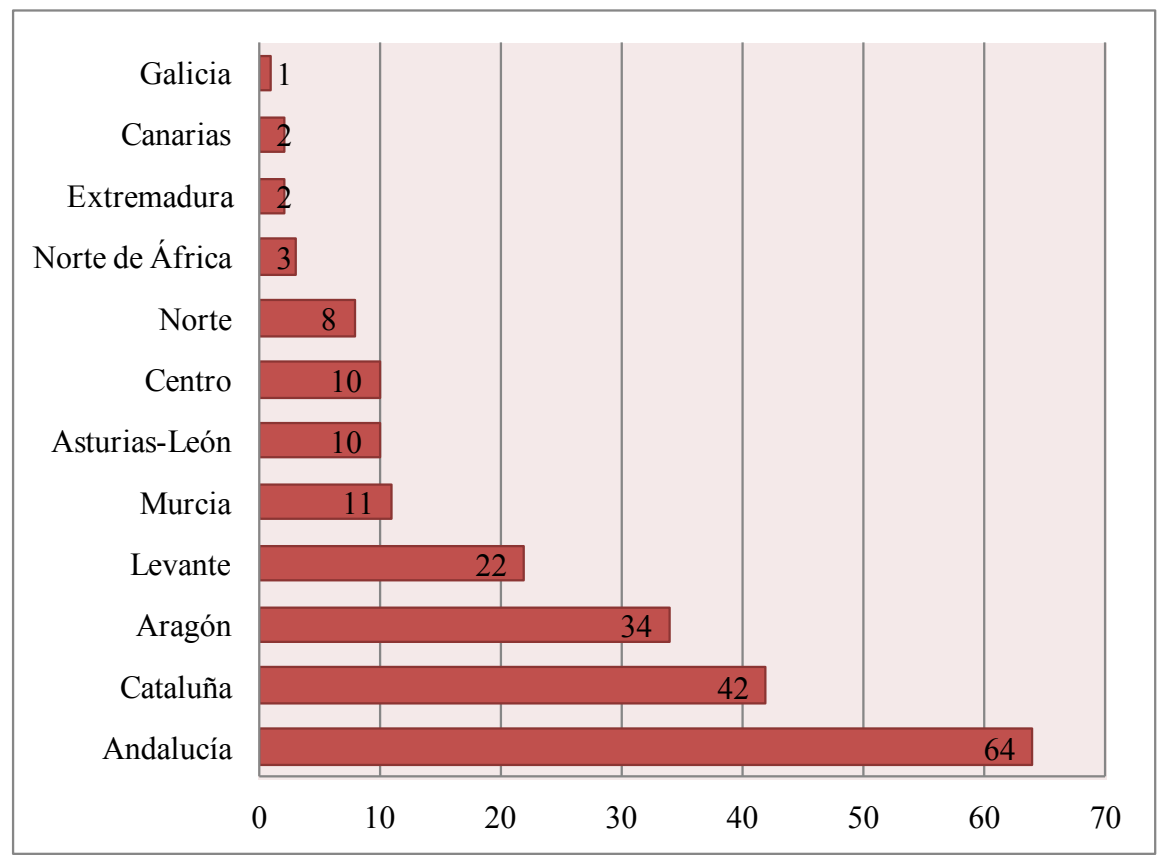

Imagen 1. Elaboración propia basada en la consulta de la prensa ácrata para el periodo 1930-1938.

En relación a la distribución geográfica de estos grupos de afinidad juveniles, vuelven a sobresalir las regiones de Andalucía y Cataluña, seguidas nuevamente por Aragón y Levante, como las regiones con mayor presencia juvenil libertaria. Mientras Andalucía es el territorio con mayor número de grupos, la provincia más poblada vuelve a ser Barcelona con un total de 32 agrupaciones, seguida esta vez por Cádiz con 22. A pesar de los datos apuntados, estamos ante un tipo de colectivo difícil de identificar y que en regiones donde los grupos son minoritarios, las referencias a éstos serán escasas o nulas, como en el caso de Galicia (con el grupo anarquista juvenil Vida y Acción ${ }^{26}$ ), lo cual no significa que no existieran agrupaciones de jóvenes, unido a que muchas de estas agrupaciones se iban a encontrar con problemas de logística debido a la falta de recursos y al reducido número de miembros, les impide disponer de local propio o disponer de los materiales necesarios para el inicio de su función. Por ello, se convierte en un habitual el uso de espacios cedidos previamente por la organización sindical, favoreciéndose así no sólo el establecimiento de

\footnotetext{
25 Tierra y Libertad (Barcelona), 04-10-1934; Tierra y Libertad (Barcelona), 30-08-1934, p. 3; Tierra y Libertad (Barcelona), 16-09-1932, p. 2; Tierra y Libertad (Barcelona), 03-06-1932, p. 3; Tierra y Libertad (Barcelona), 11-11-1932, p. 2.

26 Brazo y Cerebro (A Coruña), 01-01-1936.
} 
cuadros internos de solidaridad, sino también acercándose recortando las distancias existentes entre la CNT y la FAI. Así sucede con el grupo Amor y Libertad onubense que se reunía asiduamente en el edificio del Sindicato cenetista de la Edificación de Huelva. Por otro lado, y en relación a las edades de sus componentes, aunque todos estos colectivos aparecen bajo el apelativo común de "jóvenes", fluctúan en un amplio marco generacional que incluye desde niños y jóvenes de 12 a 16 años -como los componentes del grupo La Senda del Bien de Caravaca-, hasta adolescentes y hombres de más de treinta. Este último caso es el de Antonio Soto Moreno "Choco", que fuera secretario del grupo Los Sin Patria de Chiclana y que en 1936, el año de su creación y fusilamiento, contaba 29 años. La veintena era la edad habitual de los principales responsables de los organismos juveniles libertarios -Fidel Miró, secretario del Comité Regional de la FIJL catalana tenía 24 años en el 36, mientras que Gregorio Gallego, a la sazón su homónimo en el Comité Peninsular de las JJLL madrileñas, contaba $29{ }^{27}$.

La mayoría de las agrupaciones, sin embargo, están compuestas por militantes de todas las edades, como es el caso de Los de Ayer y los de Hoy de Barcelona o Ariel de Valencia, entre otras. Resulta difícil precisar la cifra exacta de los miembros que las componen debido a la utilización por parte de la prensa de fórmulas genéricas como "unos cuantos compañeros", "unos cuantos muchachos", "varios anarquistas de ambos sexos", "varios camaradas", "grupo de militantes reducido", "pequeño núcleo de compañeros", entre otras. Pero tras estas descripciones un tanto laxas, el número habitual oscila entre 3 y 15 militantes, siendo las más habituales aquellas compuestas por unos cuatro-Los Vengadores de El Rubio, Los Nuevos Titanes de Almodóvar del Río, Los Iguales de Aznalcóllar o Los Afines de Sevilla-, cinco -Los Luchadores de la Libertad de Camas, Armonía de Guadalcanal, Vida de Lebrija, Redención de Medina Sidonia, etc.- y seis miembros -Espartaco de Castro del Río, Los Cosmopolitas de Gerena, Los Increíbles de Motril, Ideal de Ronda, Vida Libre de Almería, etc.-. También hay excepciones, como los casos de Luz y Paz de Medina Sidonia o Los Inadaptados de Castro del Río que, entre 1932 y 1934 respectivamente, alcanzaron la cifra de 30 afiliados. El grupo con mayor número de miembros fue la Agrupación Cultural Estudios de Barcelona que, en 1931, estaba formada por un centenar de militantes de ambos sexos. En general, la identidad del grupo se define por la denominación elegida, siendo ésta muy amplia y variada. Se evidencia que la representación de la percepción colectiva del ideal se basa en un proceso de selección previo en el que participaban todos sus componentes. Los nombres más comunes se corresponden con valores, ideas y aspiraciones que sus miembros querían transmitir con su actividad proselitista (Libertad y Justicia, Los sin Fronteras, Parias hacia la Emancipación, Vida Nueva, Acción Directa, etc.). Asimismo, un análisis pormenorizado de los nombres adoptados permite establecer una jerarquía clara de los más habituales ${ }^{28}$.

27 Tierra y Libertad (Barcelona), 17-03-1933, p. 2; Tierra y Libertad (Barcelona), 05-06-1936; Tierra y Libertad (Barcelona), 10-07-1936, p. 5; Gallego, Gregorio: Madrid corazón que se desangra, Madrid, Ed. G. del Toro, 1976, p 9; Guzmán Martín, Sebastián: Luces y sombras de la historia de Chipiona. Segunda República, Guerra Civil y represión militar, Cádiz, Universidad de Cádiz-Ayuntamiento de Chipiona, 2008.

28 Tierra y Libertad (Barcelona), 30-01-1937, p. 7; Tierra y Libertad (Barcelona), 05-09-1931, p. 2; Tierra y Libertad (Barcelona), 26-12-1931, p. 3; Tierra y Libertad (Barcelona), 12-08-1932, p. 2; Tierra y Libertad (Barcelona), 02-09-1932, p. 2; Tierra y Libertad (Barcelona), 18-11-1932, p. 2; Gutiérrez Molina, José Luis: 
Gráfico IV. Principales temas que dan nombre a los grupos de afinidad.

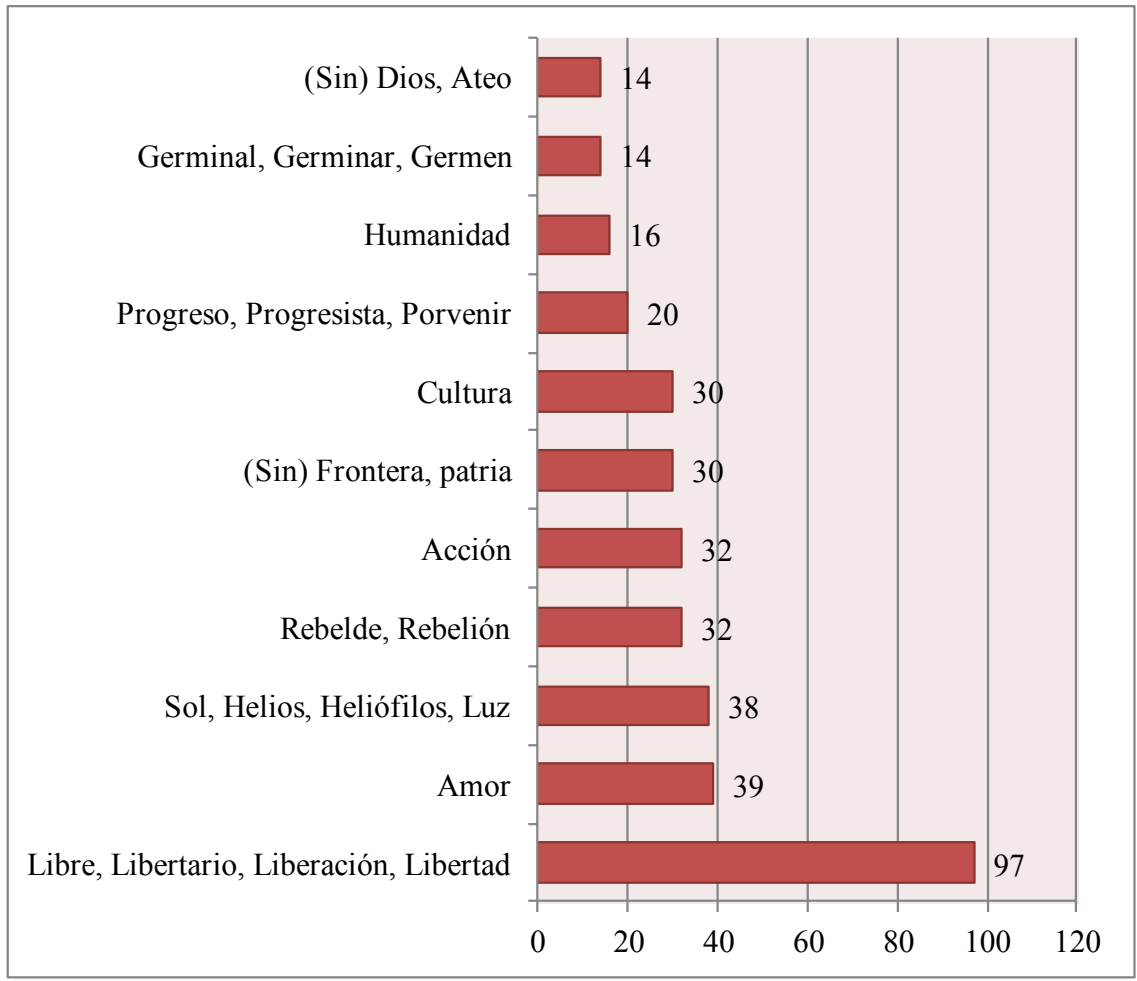

Imagen 1. Elaboración propia basada en la consulta de la prensa ácrata para el periodo 1930-1938.

El principio dominante que se repite en hasta un total de 97 agrupaciones es el que incluye conceptos relacionados con la "Libertad" (libre, libertario, liberación y libertad), remarcándose así no sólo el carácter antiestatista del movimiento anarquista, sino además reafirmándose la esencia básica y filosófica que caracterizaba a la ideología ácrata ${ }^{29}$. En segundo lugar destacan los grupos que hacen referencia al concepto del "Amor", apareciendo este seguido siempre de otros principios básicos en una concepción del mismo como esencia básica para la vida futura. Se trata de una idea que trasciende su adscripción sentimental o amorosa para significar desprendimiento, solidaridad y afectividad ${ }^{30}$. Y, en tercer lugar, predominan aquellos elementos naturales relacionados con lo solar o lumínico (sol, helios, heliófilo y luz), dada la importancia que tenía la idea de naturaleza y la fuerza de lo luminiscente como paralelismo metafórico de la potencia difusora del ideal anarquista ${ }^{31}$.

La idea revolucionaria: el anarquismo organizado en Andalucía y Cádiz durante los años treinta, Madrid, Las Siete Entidades, 1993; González Fernández, Ángeles: Utopía y realidad..., pp. 86, 87.

29 Agrupaciones como Amanecer Libertario (Daroca), Aurora Libre (Fabero del Bierzo), Liberación (Betanzos), Libertad Futura (Sevilla) y Juventud Libertaria Galán (Gandía), entre otras.

30 Agrupaciones como Amor Libre (Alcañiz), Amor sin Cadenas (Bilbao), Amor y Armonía (Casas Viejas) o Amor y Voluntad (Barcelona).

31 La regional en la que predominarían la mayoría de grupos que hacían referencia a lo lumínico en su denominación fue la región andaluza con hasta un total de 23 agrupaciones de las 38 existentes a nivel nacional: ;Helios! (Jerez de los Caballeros), Hacia la Luz (Huelva), Heliófilo (Algeciras), Heliófilo (San Roque), Helios (Sevilla), 
Junto a estas acepciones sobresalen otras que remarcan ideas que los anarquistas españoles perciben de su propia ideología: "rebelde" o "rebelión" -término relacionado con la idea de la acción directa y un espíritu combativo contra las injusticias sociales- ${ }^{32}$; "acción" - simboliza la idea de la gimnasia revolucionaria y la necesidad de actuar activamente para la transformación de la sociedad-33; "sin patria" o "sin frontera" -aboga por la idea del internacionalismo obrerista y se manifiesta en contra de los Estados-nación-34; "cultura" -entendida como saber universal en el que se fusionan lo sentimental, lo humano y lo material-35; "progreso", "progresista" y "porvenir" -alude a la aspiración de la mejora constante de la sociedad y el ser humano a lo largo de la historia-36; "humanidad" -concepto relacionado con el internacionalismo y subrayando el componente humano como el elemento cohesionador frente a las ideas de patria o nación- ${ }^{37}$; "germinar" -idea relacionada con la percepción de la naturaleza como madre creadora- ${ }^{38}$; y "sin Dios" y "ateo" -refleja el carácter antirreligioso del anarquismo español en su abierta hostilidad contra la religión y la Iglesia católica- ${ }^{39}$.

El principal interés de estos colectivos es conseguir una incidencia real en su barriada o ciudad, de ahí que cada grupo se fije una meta concreta y supuestamente realizable. Por ejemplo, el grupo Ideas de Barcelona se propone la creación de un Ateneo libertario, Luz y Armonía de Utrera proyecta crear una escuela racionalista y Espartaco de Gironella centra sus recursos en publicar un periódico que sea su portavoz, porque para estos colectivos tan importante es existir como tener voz propia. Otros colectivos centran sus esfuerzos en la defensa de aspectos concretos como el antimilitarismo, el sindicalismo -especialmente aquellas agrupaciones ligadas al treintismo ${ }^{40}$-, el naturismo -mediante la celebración de excursiones al campo o a la

Juventud Cultural Amantes de la Luz (Málaga), Los Heliófilos (La Línea de la Concepción), Luz (Algeciras), Luz de Acracia (Nerva), Luz de Andalucía (Málaga), Luz del Porvenir (Alhaurín de la Torre), Luz en la densa Obscuridad (Olvera), Luz en las Tinieblas (Jerez de la Frontera), Luz Libertaria (Sanlúcar de Barrameda), Luz y Armonía (Alosno), Luz y Armonía (Utrera), Luz y Paz (Medina Sidonia), Luz y Progreso (Almodóvar del Río), Luz y Rebeldía (Alcalá de los Gazules), Luz y Vida (Coria del Río), Luz y Vida (Puertollano), Sol y Tierra (Palma del Río) y Sol y Vida (Málaga).

32 Entre los que destacan: Águilas Rebeldes (Mataró), Rebelde Renacer (Barcelona), Joven Rebelde (Madrid), Rebelión (Tánger), entre otros.

33 Entre los que destacan: Acción Anárquica (San Fernando), Acción y Pensamiento (Marchena), y Espiritu y Acción (Córdoba), entre otros.

34 Entre los que destacan: Derribando fronteras (Ripollet), Los Simpatria (Ceuta) y Los sin Fronteras (Algemesí), entre otros.

35 Entre los que destacan: Pro-Cultura Libre (La Campana), Acción y Cultura (Elda), Cultura Libertaria (Melilla) y el Grupo Cultural Ecléctico (Sitges), entre otros.

36 Entre los que destacan: Aurora del Porvenir (Cazorla), Hacia el Porvenir (Barcelona), y Progreso (Oliva de la Frontera), entre otros.

37 Entre los que destacan: Humanidad Libre (Granada), Humanidad Nueva (Sagunto) y Nueva Humanidad (Lebrija), entre otros.

38 Entre los que destacan: Germen (Barcelona), Germinal (Petrel) y Germinar (Cádiz), entre otros.

39 Entre los que destacan: Ni Dios ni Amo (San Juan del Puerto), Sin Dios y sin Chupópteros (Granada), y Ateos sin Ley ni Patria (Cebolles de Abajo), entre otros.

40 El término de "treintismo" procede de un documento denominado Manifiesto de los Treinta (1931) y firmado por una treintena de cenetistas históricos (como Ángel Pestaña, Juan López o Joan Peiró) en el que al principio de la Segunda República defendían una visión más moderada del momento histórico y la necesidad de postergar el hecho revolucionaria ante la escasa preparación de la militancia. Enfrente tenía la idea de la "gimnasia revolucionaria" que defendía que no era necesario la plena capacitación de los militantes para implantar el comunismo libertario y que estaba defendida mayoritariamente por la FAI. El enfrentamiento entre ambas corrientes provocó la expulsión de la CNT de los críticos que se constituyeron, primero, los llamados Sindicatos de Oposición, y 
playa- y el aprendizaje del esperanto/ido, como lengua internacional que haga innecesarios los idiomas nacionales ${ }^{41}$.

\title{
2. La Guerra Civil como factor de jerarquización del asociacionismo ácrata
}

\begin{abstract}
La tradicional autonomía y descentralización del asociacionismo ácrata iba a experimentar un proceso radical de transformación a partir de 1936. El nuevo marco originado tras el 18 de julio con la CNT ocupando posiciones de poder dentro del Estado republicano, iba a condicionar no sólo la participación de la CNT en el conflicto, sino provocar cambios en la estructura interna de la FAI y, por ende, de los grupos de afinidad. Estos cambios se produjeron de forma paulatina pero siempre en la misma dirección: controlar jerárquicamente las principales estructuras de la movilización anar-
\end{abstract}

después, algunos de ellos, con Ángel Pestaña, acabaron fundando el Partido Sindicalista. Para profundizar en el conocimiento del treintismo: Vega, Eulàlia: Anarquistas y sindicalistas durante la Segunda República: la C.N.T. y los Sindicatos de Oposición en el País Valenciano, Valencia, Edicions Alfons el Magnànim, 1987; Pestaña, Ángel, Por qué se constituyó el Partido Sindicalista, Madrid, Ed. Zero, 1969.

41 La relación del esperanto con el anarquismo español fue siempre más estrecha que con el socialismo, a pesar de que en 1928 el PSOE aprobase una resolución para su enseñanza en los centros obreros a su cargo. Esta norma, sin embargo, apenas tuvo incidencia real ni se formaron organismos para favorecer su extensión a nivel nacional dentro de los círculos socialistas. Mientras, para el movimiento libertario la enseñanza del esperanto y el ido se erige en parte indisoluble de la cultura ácrata. El fomento de su aprendizaje se aborda de múltiples maneras, incluso a través de la realización de viajes de propaganda y alfabetización a cargo de militantes que van de pueblo en pueblo enseñando, entre otras materias, el esperanto. En esta labor destacó especialmente el valenciano José Pellicer Gandía, famoso por ser uno de los fundadores de la Columna de Hierro durante la Guerra Civil. Sin embargo, la vía más común para el conocimiento de la lengua fue a través de la realización de cursos - por correspondencia y gratuitos; basados en los impartidos por la Sociedad Idista Española en 1930- y de clases presenciales en los ateneos libertarios. En esta labor destacaron grupos como la Agrupación Cultural Estudios (Esparraguera), el Grupo Idista Luz del Clot (Barcelona) y el Grupo Idista Rebela Rinasko (Barcelona), así como la sección Idista del Ateneo de Divulgación Social de Soria que llegó a ofrecer clases gratuitas a los obreros que demostraran pertenecer a la CNT. Durante la guerra, estas labores no solo no cesaron, sino que en agosto de 1936, anarquistas catalanes crearon la Liga Ibérica de Esperantistas Antiestatales con sede en Barcelona y el fomento de este idioma se realizaría con la publicación de revistas o boletines completamente en esperanto, en los que se informaba del conflicto y el día a día de los milicianos en retaguardia. Esta labor fue ejercida principalmente por la Oficina de Propaganda de la CNT-FAI, cuyo compromiso con su extensión fue notorio, y la sección de esperanto de la CNT barcelonesa publicaría el titulado "Informa bulteno" (Boletín de información), que nacía para contrarrestar al vocero comunista "Proleta Vocho" (Voz Proletaria). Además, dentro de las distintas cadenas de radio controladas por la CNT en Cataluña, se emitía diariamente secciones de media hora sobre las novedades del día en el idioma esperantista. Informe Bulteno (Barcelona), 10-12-1937, p. 4; Tierra y Libertad (Barcelona), 01-07-1932, p. 2; Tierra y Libertad (Barcelona), 28-10-1932, p. 2; Tierra y Libertad (Barcelona), 22-07-1932, p. 2; Cultura Libertaria (Barcelona), 14-10-1932, p. 2; Cultura Libertaria (Barcelona), 08-01-1932, p. 3; Cultura Libertaria (Barcelona), 11-01-1932, p. 3; Sindicalismo (Valencia), 15-09-1933, p. 2; Tierra y Libertad (Barcelona), 24-01-1936, p. 2; Tierra y Libertad (Barcelona), 05-07-1935, p. 1; El Sembrador (Igualada), 27-01-1933, p. 3; Estudios (Valencia), agosto de 1932, p. 5; Trabajo (Soria), 23-08-1931, p. 4; ;Liberación! (Barcelona), septiembre de 1935, p. 105; El Porvenir del Obrero (Alayor), 1308-1932, p. 3; Solidaridad Obrera (Barcelona), 13-11-1931, p. 1; Solidaridad Obrera (Barcelona), 03-12-1931, p. 7; Solidaridad (Barcelona), 11-04-1936, p. 3; Solidaridad Obrera (Valencia), 24-12-1932, p. 2; La Revista Blanca (Barcelona), 30-08-1935, p. 819; Trabajo (Soria), 22-11-1931, p. 3; Solidaridad Obrera (Barcelona), 16-08-1936, p. 13; Cultura y Acción (Alcañiz), 21-07-1937, p. 2; Solidaridad Obrera (Barcelona), 23-09-1036, p. 3; Masjuan, Eduard: La ecología humana en el anarquismo ibérico: urbanismo orgánico o ecológico, neomalthusianismo y naturismo social, Barcelona, Icaria, 2000, p. 415; Navarro Navarro, Francisco Javier: Ateneos y grupos ácratas..., p. 506; Navarro Navarro, Francisco Javier: A la revolución por la cultura. Prácticas culturales y sociabilidad libertarias en el país Valenciano, 1931-1939, Valencia, Servicio de Publicaciones de la Universitat de Valencia, 2004, pp. 85-99; Amorós, Miguel: José Pellicer. El anarquista integro: vida y obra del fundador de la heroica Columna de Hierro, Barcelona, Virus editorial, 2009, p. 78. 
quista. Tras los primeros meses del conflicto, tanto el Comité Nacional de la central sindical como el Comité Peninsular de la organización faísta, inician un proceso de control creciente de los portavoces principales de la prensa ácrata-Solidaridad Obrera y Tierra y Libertad - para justificar la llegada de los ministros anarquistas al gobierno central e intentar un mayor control sobre la militancia. Una transformación que pasa porque la "Específica" se convierta en el organismo rector de las nuevas decisiones políticas, igualando así en influencia y predominio a la central sindical. Se pasaba así de un modelo descentralizado a un molde centralista que desembocaría en la creación del Comité Ejecutivo del Movimiento Libertario Español en abril de $1938^{42}$.

La nueva estructuración de los grupos de afinidad comienza a introducirse a partir de septiembre de 1936, adoptándose por un método conciliador basado en la convocatoria de reuniones en las distintas federaciones locales de las agrupaciones para convencerlas de la necesidad de adoptar cambios. Incluso, la defensa del reformismo es asumida por muchas de estas agrupaciones, como la barcelonesa Los de Ayer y los de Hoy, que aboga desde las páginas de Solidaridad Obrera de Barcelona que la FAI acepte la situación actual que sitúa al anarquismo dentro de las fuerzas gubernamentales. La nueva propuesta se basa principalmente en la ampliación de la base de ingreso en la "Específica" para aumentar así el número de afiliados y consolidar una posición predominante y más sólida entre los trabajadores ${ }^{43}$ :

Se nos objetará que ampliando la base en forma colectiva pueden filtrarse elementos fascistas, y aún aceptándolo, poco daño nos podrán inferir si descartamos de los cargos de responsabilidad a todo aquel que no tenga una larga y probada ejecutoria de militante, avalada por una moral revolucionaria ${ }^{44}$.

Dicha ampliación suponía la relajación de las exigencias previas permitiendo que ingrese en las organizaciones anarquistas todo aquel que tuviera un mínimo de interés, pero sin tener que demostrar su militancia o idealismo y comunión con las ideas anarquistas. El motivo real tras esta decisión es que, en plena efervescencia del acceso ácrata a las instituciones del Estado, se persigue aumentar la base de seguidores para pugnar con otras organizaciones y consolidar una situación de predominio político en la esfera pública. El pragmatismo se extiende de este modo y oficialmente por un movimiento en el que la necesidad de la revolución de las conciencias como esencia de una militancia activa queda postergada sine die y en la que, además, se remarca que no hace falta "preparación cultural por parte del pueblo" para vivir en una "democracia social libre sin clases, ni Estado" 45 . Mientras, el Comité Peninsular faísta justifica los cambios argumentando que la estructura de los grupos de afinidad está desfasada y es propia del periodo de la clandestinidad y no de la situación extraordinaria que se vivía entonces. Con esta decisión unilateral y "desde arriba", la FAI no sólo impide procesos de participación directa de la militancia que pudieran estar en su contra, sino que imposibilita el debate interno sobre la nueva configura-

42 Martín Nieto, Isaac: “Anarcosindicalismo, resistencia y grupos de afinidad...”, p. 600; Saña, Heleno: La revolución libertaria..., pp. 283, 284; Navarro Navarro, Francisco Javier: Ateneos y grupos ácratas ..., pp. 531-535.

43 El grupo tenía entre sus filas a veteranos militantes anarquistas como Felipe Cortiella (tipógrafo, sociólogo y escritor) o Jaime Rabasa (pintor de profesión que militaba en las filas anarquistas desde 1902). Ambos fallecían en agosto de 1937. Solidaridad Obrera, 31/08/1938, p. 3; Esfuerzo, 07/10/1937, p. 1; Solidaridad Obrera, 01/08/1937, p. 2; Vida Nueva, 11/09/1936, p. 2.

$44 \quad$ Solidaridad Obrera (Barcelona) 15-12-1936, p. 2.

45 Solidaridad Obrera (Barcelona), 15-12-1936, p. 2. 
ción que se le estaba dando al asociacionismo ácrata, argumentando que la situación de conflicto bélico y la disgregación de los comités impedía cualquier tipo de consulta. La celeridad con la que se quisieron implementar los cambios pretendía reducir exponencialmente el incremento desorbitado de militantes que habían experimentado partidos como el PCE, que a partir de 1936 logra un sorprende ascenso en sus porcentajes de afiliación (de 17.342 militantes en diciembre de 1935, pasarían a los 339.682 afiliados en noviembre de 1937). Algo similar sucedía con el PSUC, el rival de la CNT por la hegemonía obrera en Cataluña, que desde su fundación en julio de 1936 a marzo de 1937 había pasado de 5.000 a unos 50.000 afiliados, lo que suponía de facto una amenaza para el dominio de la $\mathrm{CNT}^{46}$.

La nueva estructura organizativa sería adoptada definitivamente durante el Pleno Peninsular de Regionales de la FAI celebrado en Valencia entre el 4 y el 7 de julio de 1937. Se apuesta por eliminar las pequeñas agrupaciones de afinidad para sustituirlas por grandes núcleos de militantes, previa legalización de cada entidad según una nueva normativa que debía ser previamente aprobada por el gobierno. De este modo, las nuevas formas de organización de la militancia ácrata no sólo eran modificadas y centralizadas para favorecer su control interno por parte de la organización ácrata, sino que se las sometía a la regulación estatal limitando enormemente el carácter antisistema de estos colectivos. Entre los nuevos requisitos está la necesaria aceptación de unos estatutos generales, en cuyo artículo 14 se señala que cada grupo debe presentar por duplicado un ejemplar de los estatutos, del libro de caja, de las actas y de los afiliados a la Comisaría Delegada del gobierno regional competente. La nueva normativa afectaba principalmente a las grandes ciudades o sitios en los que hubiera varios grupos de afinidad que eran ahora obligados a fusionarse para poder seguir existiendo. Para cumplir este objetivo, cada Federación Local debía además nombrar una subcomisión encargada de la reorganización de los mismos por distritos ${ }^{47}$.

Con la nueva organización, la admisión de nuevos miembros pasa a estar regulada por una Comisión de Adhesiones que es la encargada de establecer una serie de principios básicos que el postulante debe aceptar antes de entrar: luchar contra la explotación humana, abogar por la socialización de los medios de producción, desarrollar libremente la ciencia, establecer una enseñanza totalmente gratuita y racionalista, oponerse a cualquier tipo de dictadura, reclamar una sociedad sin clases ni privilegios y defender una federación libre de los pueblos de Iberia. Después de la aceptación de estos principios, se pasa a una segunda fase en la que debe conseguir que dos afiliados le avalen y hablen positivamente de él, quedando la responsabilidad final de la decisión a juicio de la comisión. Con esta medida se pretende ampliar los requisitos de ingreso y permitir que más gente ingresara en las filas anarquistas, pero siempre controlando el acceso para evitar la entrada de elementos indeseados ${ }^{48}$.

46 Hernández Sánchez, Fernando: El PCE en la Guerra Civil, Tesis doctoral, Madrid: UNED 2010, pp. 352-356; Puigsech Farràs, Josep: “Guerra Civil y militancia en Cataluña. Las particularidades del perfil ideológico y social de los militantes del PSUC, 1936-1939”, Hispania, 62/210 (2002), pp. 260-267; Martín Nieto, Isaac: “Anarcosindicalistas, resistencia y grupos de afinidad...", pp. 601-603.

47 En el caso de la Federación Local de Barcelona, su secretario (Alejandro G. Gilabert), impulsó la celebración de reuniones con los grupos de las distintas barriadas para explicar el informe de la comisión reorganizadora y designar el lugar físico que ocuparía en el futuro cada uno de estos macro grupos. De las 25 agrupaciones que en abril de 1937 formaban parte de la Federación Local de Barcelona, a partir del Pleno de Valencia la cifra se reduce a 8 , correspondiéndose así con el número de distritos en los que se dividía la ciudad. Solidaridad Obrera (Barcelona), 27-08-1937, p. 6; Gerona C.N.T. (Gerona), 05-11-1937, p. 4.

48 Via Libre (Badalona), 08-01-1938, p. 6. 
Este proceso de jerarquización y transformación de las bases de la FAI sería criticado por algunos sectores que denunciarían la inclinación demasiado "política" que estaba tomando el movimiento anarquista. Felipe Aláiz - antiguo director de Tierra y Libertad y Solidaridad Obrera - critica así en noviembre de 1937 desde el órgano de las JJLL de Cataluña las inclinaciones políticas que parece albergar la "nueva" FAI: "Camaradas de la F.A.I.: dejad de llamaros anarquistas y el horizonte quedará aclarado, aireado, libre. La anarquía os parece un anacronismo [...] y los anarquistas os parecen unos barbudos sin raíz en la realidad [...]"49.

Las críticas se dirigen principalmente contra un grupo de anarquistas muy relacionados con América Latina y que son señalados como los principales impulsores de estas medidas. Estos, que serían conocidos despectivamente como la "legión extranjera", tienen en Diego Abad de Santillán, Fidel Miró y Germinal de Souza a sus máximos exponentes. Mientras, anarquistas críticos como José Peirats, consideran que la burocratización del movimiento libertario con la creación de comités y subcomités, además de la disposición de la CNT de entrar por acceder al poder demostraba "el hambre de gobierno de la CNT"50. El que fuera miembro de la Columna Durruti consideraba que aquello era un grave error y una traición manifiesta al movimiento anarquista español al querer convertirlo en parte del Estado republicano. Los enfrentamientos internos que se derivaron de estas transformaciones internas llevarían a, como hizo Fidel Miró, criticar la entrada de ministros anarquistas en el gobierno y focalizar su censura contra Federica Montseny, erigida en una de las líderes principales del anarquismo en guerra ${ }^{51}$.

Por contra, esta tendencia "política" tiene entre sus principales partidarios a Juan López Sánchez, antiguo treintista, y uno de los negociadores de la CNT para la existencia de ministros anarquistas. En septiembre de 1938, López completa el giro estatalista del movimiento ácrata con la publicación en la revista Timón -dirigida por Abad de Santillán- de unos artículos en los que señala la necesidad de fundar propiamente dicho un partido político libertario; retomándose otra vez así el intento fallido que llevó a cenetistas como Ángel Pestaña a fundar el Partido Sindicalista durante la República. En defensa de esta tesis, que se topó con el principal escoyo de la derrota republicana en la guerra, se difunde la idea de la necesidad de que existan líderes dentro de los movimientos de masas, incluso del anarquismo. Este discurso cobró tanto fuerza y aceptación entre los sectores rectores del anarcosindicalismo, que críticos como Fidel Miró, no estaban en contra de la existencia de "guías" del pueblo, sino en una mala praxis del liderazgo o la extensión de una especie de culto a la personalidad (como había sucedido con el ya fallecido Durruti). En su opinión, el liderazgo es un fenómeno natural inevitable, benéfico para la sociedad y que siempre había existido. Incluso, para el que fuera secretario de las JJLL y que firmaba con el seudónimo de Mirlo, la principal figura de la época, el "líder por excelencia" del anarquismo español, no era otro que Juan García Oliver -tildado en numerosas ocasiones de anarcobolchevique por su dirigismo-, al considerarlo un referente vital por su valentía, carisma, trayectoria, lucidez, vehemencia y, sobre todo, dotes oratorias ${ }^{52}$.

\footnotetext{
Esfuerzo (Barcelona), noviembre de 1937, p. 13.

Peirats, José: Los anarquistas en la Guerra Civil Española, Buenos Aires, Alfa, 1964, p. 290.

Miró, Fidel: Anarquismo y anarquistas, México D.F., Editores Mexicanos Unidos, 1979, pp. 208-210.

Miró, F., Anarquismo y anarquistas, pp. 32, 33, 226, 227.
} 
De este modo, se empiezan a romper las viejas reticencias internas sobre la existencia del dirigismo de una élite dominante en una ideología tan heterodoxa como la ácrata. La adopción y aceptación de conceptos como "liderazgo", "partido", "control" y "dirigentes" lleva al anarquismo español organizado a una situación totalmente nueva en todos sus años de existencia. La derrota bélica en 1939 fue lo único que pudo romper, sin embargo, esta rompería, sin embargo, esta transformación profunda que se estaba orquestando en el seno del movimiento libertario español. Al final parecía cumplirse a modo de epitafio el eslogan cenetista de moda durante la guerra, y reivindicado como testamento político del líder obrero y mártir por excelencia del anarquismo de esos años, Buenaventura Durruti: "Renunciamos a todo, menos a la victoria" 53 .

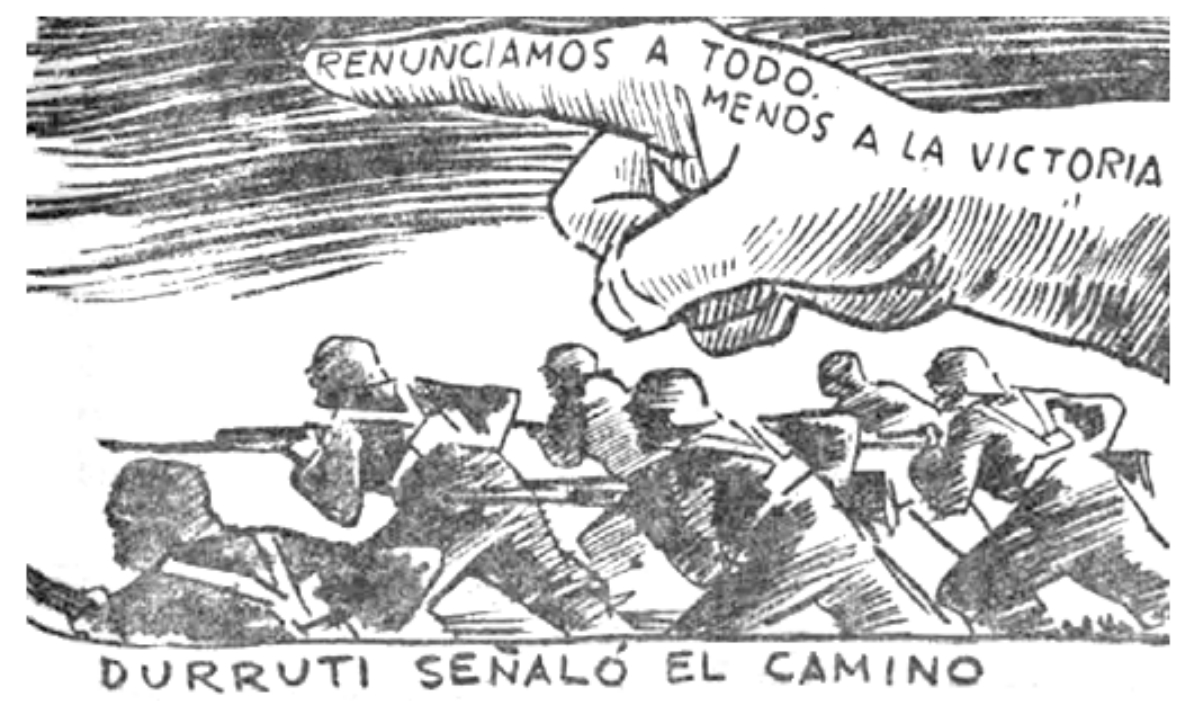

Imagen 3. Ilustración publicada en el periódico Solidaridad Obrera de Barcelona. Solidaridad Obrera (Barcelona), 09-04-1938, p. 1.

\section{Conclusiones}

Los grupos de afinidad representaron en el anarquismo la célula básica en torno a la que construir la sociabilidad y la propaganda libertaria en pos de la gran aspiración ácrata de la instauración del comunismo libertario. La función de estos colectivos, mitad militantes y mitad amigos, era la de, a través de todo tipo de actividades culturales y de acción, influir en la vida diaria de sus vecinos para extender sus ideas entre la clase obrera como única solución a la tan ansiada revolución social. El objetivo del presente artículo ha sido realizar una aproximación lo más certera y exhaustiva posible de las características, historia, funcionamiento y razón de ser de

53 Esta situación es la que lleva a Heleno Saña a utilizar el término "Politburó" para referirse a esta "elite" ácrata que copaba los principales puestos dirigentes de un movimiento libertario que a finales de la década de los treinta había acabado por jerarquizarse y aceptar las tesis estatalistas que siempre condenó. SAÑA, H., La revolución libertaria, pp. 284, 294, 295; MIRÓ, F., Anarquismo y anarquistas, pp. 32, 33, 226, 227. 
estas agrupaciones, centrándonos en los años treinta y sin las cuáles, la extensión del cenetismo en España no hubiera tenido la magnitud que tuvo. Aunque resulta muy difícil establecer una cifra real del total de grupos anarquistas activos durante toda la década, la cifra aportada de 785 grupos, procede de un análisis pormenorizado de la prensa consultada. Esto no significa que la ausencia de grupos en ciudades o regiones conlleve la aseveración de que en dichos lugares no existieran grupos, sencillamente que estos no han dejado presencia en la prensa libertaria consultada. Sin embargo, las limitaciones en cuanto al acceso a las fuentes nos ha llevado a realizar un bosquejo que ha pretendido ser lo más exhaustivo posible en cuanto al número y procedencia de la prensa examinada.

La relevancia de los grupos de afinidad anarquista se evidencia en que únicamente durante la década de 1930 se crearon en España más de seiscientas agrupaciones libertarias, muchas de las cuales fueran de nueva creación. Este enorme crecimiento, después de un periodo de clandestinidad y persecución, demuestra, no sólo que las ideas ácratas seguían muy presentes en el seno del obrerismo español, sino la capacidad libertaria para encauzar las ansias de cambio y las necesidades de transformación social de parte de la clase trabajadora española. La esencia básica y más característica de estas agrupaciones fue la sintonía emocional de sus miembros, de ahí la puntualización de "afinidad". Esta conexión generaba lazos que trascendían lo puramente cultural o ideológico para actuar, especialmente durante el conflicto bélico, como clientelas encabezadas por un líder o representante que, al llegar a órganos de poder o decisión, se hacían rodear de sus amigos de militancia. Sin embargo, el estallido de la Guerra Civil y la conformación de una nueva correlación de fuerzas en el bando republicano provocaría la transformación del sistema asociativo ácrata para facilitar su articulación dentro de gobiernos teóricamente escorados hacia la izquierda obrerista. De este modo, el Estado -antiguo enemigo del anarquismo-, se convierte durante los años de guerra en aspiración para ingresar en él y así impulsar las transformaciones sociales desde su cima. Para ello, las antiguas organizaciones basadas en la afinidad y el "amiguismo", y en las que la espontaneidad y el descontrol de su creación y funcionamiento era una realidad, acaban dando paso a un control más exhaustivo del asociacionismo ácrata basado en la conformación de grandes estructuras organizativas que deben legalizar su creación y en las que el control de las mismas es asumido por la FAI, a través del creado Comité Ejecutivo del Movimiento Libertario Español (en 1938).

Se completaba así un proceso evolutivo en el que se pasaba de un modelo descentralizado a un molde centralista con colectivos gigantescos que aglutinan a un elevado número de militantes, sin rastro de afinidad emocional, y realizado en función de necesidades operativas. Este proceso de centralización, abortado por la derrota militar en 1939, ponía fin a varias décadas de organización de la militancia según la proximidad emocional de sus miembros, terminándose así con la atomización. En el fondo, y a pesar de la retórica ácrata que defiende la necesidad de avanzar hacia formas de sociabilidad menos autoritarias y con bases de afiliación más amplias, la actuación de los cuadros dirigentes de la CNT/FAI fomentó cambios en la estructura organizativa del movimiento libertario que redujeron en la práctica la diversidad e independencia de estos colectivos, disminuyendo así las críticas y el rechazo de muchos sectores, consiguiendo finalmente aumentar su control sobre la militancia. 


\section{Referencias bibliográficas}

\section{Fuentes de prensa}

La Revista Blanca (Barcelona)

Solidaridad Obrera (Barcelona)

Solidaridad Obrera (A Coruña)

Tierra y Libertad (Barcelona/Valencia)

Antorcha (Las Palmas de Gran Canaria)

Informa Bulteno (Barcelona)

Cultura Libertaria (Barcelona)

Sindicalismo (Barcelona)

El Sembrador (Gerona)

Trabajo (Soria)

¡Liberación! (Barcelona)

Estudios (Valencia)

El Porvenir del Obrero (Alayor)

Solidaridad (A Coruña)

Brazo y Cerebro (A Coruña)

Cultura y Acción (Alcañiz)

Vida Nueva (Tarrasa)

Esfuerzo (Barcelona)

Gerona C.N.T. (Gerona)

\section{Bibliografía}

Aguado, Ana, Sanfeliu, Luz: “Juventud, socialismo y compromiso político femenino: entre el asociacionismo y la militancia (1906-1931)“, Ayer, 100 (2015), pp. 47-72. Albiñana, Antonio, Arancibia, Mercedes: "La última entrevista con Gaston Leval", Tiempo de Historia, 46 (1978), pp. 10-21.

Amorós, Miguel: José Pellicer. El anarquista íntegro: vida y obra del fundador de la heroica Columna de Hierro, Barcelona, Virus editorial, 2009.

Balcells, Albert: Crisis económica y agitación social en Cataluña de 1930 a 1936, Barcelona, Ed. Ariel, 1971.

Barrio Alonso, Ángeles: Anarquismo en Asturias: 1890-1936, Cantabria, Universidad de Cantabria, 1986, pp. 381-472.

Berenguer, Sara: Entre el sol y la tormenta: treinta y dos meses de guerra (1936-1939), Barcelona, Seuba, 1984.

Bernecker, Walther: “Acción directa y violencia en el anarquismo español“, Ayer, 13 (1994), pp. 147-188.

Bookchin, Murray: Los anarquistas españoles: los años heroicos 1868-1936, Valencia, Ed. Numa, 2000.

Caro, Diego: "El anarcosindicalismo y la victoria del Frente Popular", Historia Social, 76 (2013), pp. 54-66.

Cases Sola, Adriana: “Mujeres rebeldes. Género, juventud y violencia política en la Segunda República“, Ayer, 100 (2015), pp. 73-96.

Christie, Stuart: ¡Nosotros, los anarquistas!: un estudio de la Federación Anarquista Ibérica (FAI), 1927-1937, Valencia, Universitat de València, 2010. 
Cobo Romero, Francisco, Ortega López, Teresa: Franquismo y posguerra en Andalucía Oriental. Represión, castigo a los vencidos y apoyos sociales al régimen franquista, 1936-1950, Granada, Universidad de Granada, 2005.

Cruz Martínez, Rafael: "La cultura regresa al primer plano“, en Rafael Cruz Martínez y Manuel Pérez Ledesma (eds.): Cultura y movilización en la España Contemporánea, Madrid, Alianza Editorial, 1997, pp. 13-34.

De Rol, Valentín: Ascaso, Durruti, Jover. Su obra de militantes. Su vida de perseguidos, Buenos Aires, Ediciones del Semanario Anarquista La Antorcha, 1927.

Díez Martín, Paulino: Memorias de un anarcosindicalista de acción, Barcelona, Bellaterra, 2006.

Díez, Xavier: "«Amaos y no os multipliquéis». El discurso ético-sexual del anarquismo individualista en Cataluña (1927-1937)“, Spagna Contemporánea, 21 (2002), pp. 99-124.

Domingo Álvaro, Alfonso: "Melchor Rodríguez y los Libertos", Germinal, 6 (2008), pp. 81 107.

Ealham, Chris: La lucha por Barcelona. Clase, cultura y conflicto 1898-1937, Madrid, Alianza Editorial, 2005.

Elorza, Antonio: "Hace ahora cincuenta años: la fundación de la F.A.I.!“, Tiempo de Historia, 33 (1977), pp. 4-21.

Gabriel Sirvent, Pere: "Propagandistas confederales entre el sindicato y el anarquismo. La construcción barcelonesa de la CNT en Cataluña, Aragón, País Valenciano y Baleares“", Ayer, 45 (2002), pp. 105-146.

Gallego, Gregorio: Madrid corazón que se desangra, Madrid, Ed. G. del Toro, 1976.

García Oliver, Juan: El eco de los pasos. El anarcosindicalismo en la calle, en el Comité de Milicias, en el gobierno, en el exilio, Barcelona, Ruedo Ibérico, 1978.

Garner, Jason: "La búsqueda de la unidad anarquista: la Federación Anarquista Ibérica antes de la II República“, Germinal, 6 (2008), pp. 49-79.

González Calleja, Eduardo: "Introducción“, Ayer, 59 (2005), pp. 11-19.

González Calleja, Eduardo, Souto Kustrín, Sandra: "De la dictadura a la República: orígenes y auge de los movimientos juveniles en España“, Hispania, 67/225 (2007), pp. 73-102.

González Fernández, Ángeles: Utopía y realidad. Anarquismo, anarcosindicalismo y organizaciones obreras: Sevilla, 1900-1923, Sevilla, Diputación Provincial de Sevilla, 1996.

Gutiérrez Molina, José Luis: La idea revolucionaria: el anarquismo organizado en Andalucía y Cádiz durante los años treinta, Madrid, Las Siete Entidades, 1993.

Guzmán Martín, Sebastián: Luces y sombras de la historia de Chipiona. Segunda República, Guerra Civil y represión militar, Cádiz, Universidad de Cádiz-Ayuntamiento de Chipiona, 2008.

Hernández Sánchez, Fernando: El PCE en la Guerra Civil, Tesis doctoral, Madrid: UNED 2010.

López Santamaría, Jesús: “El desafío de la «Trinidad Libertaria»: Feminismo y afeminismo en el seno del anarquismo hispano. El caso de las JJLL“, en Las mujeres y la Guerra Civil Española, Madrid, Ministerio del Trabajo e Inmigración-Instituto de la Mujer, 1991, pp. 88-96.

Martín Nieto, Isaac: “Anarcosindicalismo, resistencia y grupos de afinidad. La comisión de propaganda confederal anarquista (1937-1939)", El Futuro del Pasado, 1 (2010), pp. 597-611.

Masjuan, Eduard: La ecología humana en el anarquismo ibérico: urbanismo orgánico o ecológico, neomalthusianismo y naturismo social, Barcelona, Icaria, 2000. 
Maurice, Jacques: El anarquismo andaluz, Barcelona, Ed. Crítica, 1990.

Mintz, Frank: Autogestión y anarcosindicalismo en la España revolucionaria, Buenos Aires, Ed. Terramar, 2009.

Miró, Fidel: Anarquismo y anarquistas, México D.F., Editores Mexicanos Unidos, 1979.

Moroni, Sara: "Concha Pérez Collado“, Germinal, 5 (2008), pp. 94-114.

Nash, Mary: Mujer y movimiento obrero en España, Barcelona, Ed. Fontamara, 1981.

Navarro Navarro, Francisco Javier: Ateneos y grupos ácratas. Vida y actividad cultural de las asociaciones anarquistas valencianas durante la Segunda República y la Guerra Civil, Valencia, Direcció General del Llibre, Arxius i Biblioteques, 2002.

Navarro Navarro, Francisco Javier: A la revolución por la cultura. Prácticas culturales y sociabilidad libertarias en el país Valenciano, 1931-1939, Valencia, Servicio de Publicaciones de la Universitat de Valencia, 2004.

Oyón, José Luis: "La ruptura de la ciudad obrera y popular: espacio urbano, inmigración y anarquismo en la Barcelona de entreguerras, 1914-1936“, Historia Social, 58 (2007), pp. 123-150.

Peirats, José: Los anarquistas en la Guerra Civil Española, Buenos Aires, Alfa, 1964.

Pestaña, Ángel: ¿Por qué se constituyó el Partido Sindicalista?, Madrid, Ed. Zero, 1969.

Puigsech Farràs, Josep: "Guerra Civil y militancia en Cataluña. Las particularidades del perfil ideológico y social de los militantes del PSUC, 1936-1939“, Hispania, 62/210 (2002), pp. 259-282.

Ruipérez, María, Pérez Ledesma, Manuel: "José Peirats, la C.N.T. y la revolución social", Tiempo de Historia, 62 (1980), pp. 40-51.

Santamaría, Jesús: “Juventudes Libertarias y Guerra Civil (1936-1939)“, Studia histórica. Historia contemporánea, 1 (1983), pp. 215-222.

Saña, Heleno: La revolución libertaria. Los anarquistas en la Guerra Civil Española, Pamplona, Ed. Laetoli, 2010.

Souto Krustín, Sandra: “Introducción: juventud e historia“, Hispania, 67/225 (2007), pp. 1120.

Tarrow, Sidney: El poder en movimiento. Los movimientos sociales, la acción colectiva y la política, Madrid, Alianza Editorial, 1997.

Tavera, Susana: "Escola de rebel.lia. La joventud i l'anarcosindicalisme", en Enric UcelayDa Cal: La joventud a Catalunya al segle XX. Materiales per a una historia, Barcelona, Diputació de Barcelona, 1987, vol. I, pp. 138-151.

Tavera, Susana, Ucelay-Da Cal, Enric: “Grupos de afinidad, disciplina bélica y periodismo libertario, 1936-1938“, Historia Contemporánea, 9 (1993), pp. 167-190.

Ucelay-Da Cal, Enric: "El pueblo contra la clase: populismo legitimador, revoluciones y sustituciones políticas en Cataluña (1936-1939)“, Ayer, 50 (2003), pp. 143-198.

Vadillo Muñoz, Julián: "Desarrollo y debates en los grupos anarquistas de la FAI en el Madrid republicano“, Germinal, 4 (2007), pp. 27-65.

Vega, Eulàlia: Anarquistas y sindicalistas durante la Segunda República: la CNT y los Sindicatos de Oposición en el País Valenciano, Valencia, Edicions Alfons el Magnànim, 1987.

Vega, Eulàlia: "Mujeres y militancia en el anarquismo español (1931-1936), Spagna Contemporánea, 40 (2011), pp. 67-88.

Villa García, Roberto: “«Obreros, no votéis». La CNT y el Frente Popular en las elecciones de 1936“, Pasado y Memoria, 13 (2014), pp. 173-196.

Villa García, Roberto: La República en las urnas, Madrid, Marcial Pons, 2011. 